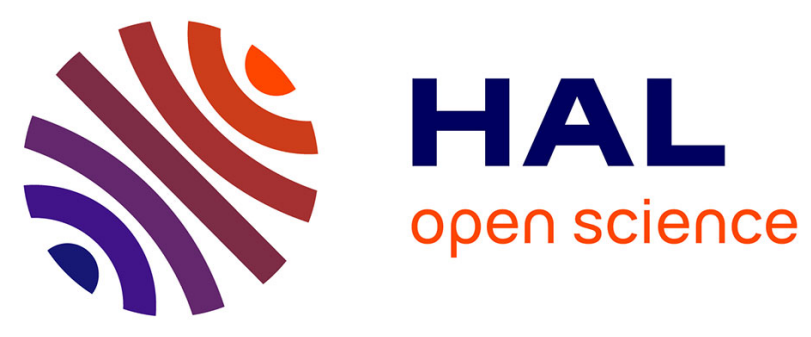

\title{
Interplay between Ret and Fap-1 regulates CD95-mediated apoptosis in medullary thyroid cancer cells
}

Valentina Nicolini, Giuliana Cassinelli, Giuditta Cuccuru, Italia Bongarzone, Giovanna Petrangolini, Monica Tortoreto, Piera Mondellini, Patrizia Casalini, Enrica Favini, Nadia Zaffaroni, et al.

\section{To cite this version:}

Valentina Nicolini, Giuliana Cassinelli, Giuditta Cuccuru, Italia Bongarzone, Giovanna Petrangolini, et al.. Interplay between Ret and Fap-1 regulates CD95-mediated apoptosis in medullary thyroid cancer cells. Biochemical Pharmacology, 2011, 82 (7), pp.778. 10.1016/j.bcp.2011.06.037 . hal-00723638

\section{HAL Id: hal-00723638 \\ https://hal.science/hal-00723638}

Submitted on 12 Aug 2012

HAL is a multi-disciplinary open access archive for the deposit and dissemination of scientific research documents, whether they are published or not. The documents may come from teaching and research institutions in France or abroad, or from public or private research centers.
L'archive ouverte pluridisciplinaire HAL, est destinée au dépôt et à la diffusion de documents scientifiques de niveau recherche, publiés ou non, émanant des établissements d'enseignement et de recherche français ou étrangers, des laboratoires publics ou privés. 


\section{Accepted Manuscript}

Title: Interplay between Ret and Fap-1 regulates

CD95-mediated apoptosis in medullary thyroid cancer cells

Authors: Valentina Nicolini, Giuliana Cassinelli, Giuditta

Cuccuru, Italia Bongarzone, Giovanna Petrangolini, Monica

Tortoreto, Piera Mondellini, Patrizia Casalini, Enrica Favini,

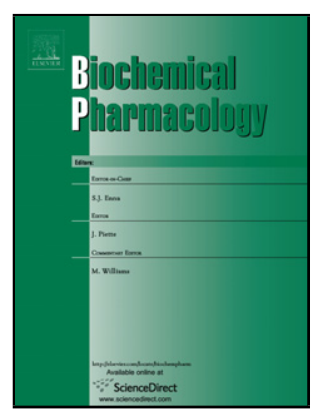

Nadia Zaffaroni, Franco Zunino, Cinzia Lanzi

PII:

S0006-2952(11)00421-7

DOI:

doi:10.1016/j.bcp.2011.06.037

Reference:

BCP 10962

To appear in: $\quad B C P$

Received date: $\quad$ 15-3-2011

Revised date: 27-5-2011

Accepted date: $\quad$ 22-6-2011

Please cite this article as: Nicolini V, Cassinelli G, Cuccuru G, Bongarzone I, Petrangolini G, Tortoreto M, Mondellini P, Casalini P, Favini E, Zaffaroni N, Zunino F, Lanzi C, Interplay between Ret and Fap-1 regulates CD95-mediated apoptosis in medullary thyroid cancer cells, Biochemical Pharmacology (2010), doi:10.1016/j.bcp.2011.06.037

This is a PDF file of an unedited manuscript that has been accepted for publication. As a service to our customers we are providing this early version of the manuscript. The manuscript will undergo copyediting, typesetting, and review of the resulting proof before it is published in its final form. Please note that during the production process errors may be discovered which could affect the content, and all legal disclaimers that apply to the journal pertain. 


\title{
Interplay between Ret and Fap-1 regulates CD95-mediated apoptosis in medullary thyroid cancer cells
}

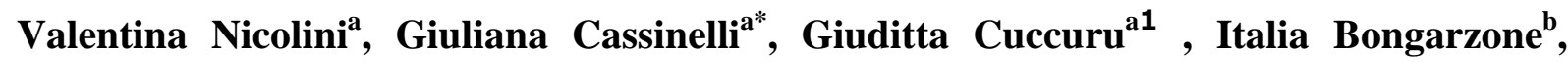 \\ Giovanna Petrangolini ${ }^{\mathrm{a} 2}$, Monica Tortoreto ${ }^{\mathrm{a}}$, Piera Mondellini ${ }^{\mathrm{b}}$, Patrizia Casalini ${ }^{\mathrm{c}}$, \\ Enrica Favini $^{\mathrm{a}}$, Nadia Zaffaroni ${ }^{\mathrm{a}}$, Franco Zunino ${ }^{\mathrm{a}}$ and Cinzia Lanzi ${ }^{\mathrm{a}}$
}

${ }^{a}$ Molecular Pharmacology Unit, Department of Experimental Oncology and Molecular Medicine, Fondazione IRCCS Istituto Nazionale dei Tumori, Milan, Italy

${ }^{b}$ Proteomics Laboratory, Molecular Mechanisms Unit, Department of Experimental Oncology and Molecular Medicine, Fondazione IRCCS Istituto Nazionale dei Tumori, Milan, Italy

${ }^{c}$ Molecular Therapy Unit, Department of Experimental Oncology and Molecular Medicine, Fondazione IRCCS Istituto Nazionale dei Tumori, Milan, Italy

"Corresponding author at: Molecular Pharmacology Unit, Department of Experimental Oncology and Molecular Medicine, Fondazione IRCCS, Istituto Nazionale dei Tumori, via Amadeo 42, 20133 Milan, Italy. Tel.: +39 02 23902202; fax: +39 02 23902692. E-mail address: giuliana.cassinelli@istitutotumori.mi.it

Present addresses: ${ }^{1}$ Laboratory of Molecular Oncology, Center for Experimental Research and Medicine (CeRMS), Università di Torino, Turin, Italy; ${ }^{2}$ Indena S.p.A., Milan, Italy 


\section{ABSTRACT}

Emerging evidence suggests that Ret oncoproteins expressed in medullary thyroid cancer (MTC) might evade the pro-apoptotic function of the dependence receptor proto-Ret by directly impacting the apoptosis machinery. Identification of the molecular determinants of the interplay between Ret signaling and apoptosis might provide a relevant contribution to the optimization of Ret-targeted therapies. Here, we describe the cross-talk between Ret-M918T oncogenic mutant responsible for type 2B multiple endocrine syndrome (MEN2B), and components of death receptor-mediated extrinsic apoptosis pathway. In the human MEN2Btype MTC cell line MZ-CRC-1 expressing Ret-M918T, Ret was found associated with Fap-1, known as inhibitor of the CD95 death receptor trafficking to the cell membrane, and with procaspase-8, the initiator pro-form caspase in the extrinsic apoptosis pathway. Cell treatment with the anti-tumor Ret kinase inhibitor RPI-1 inhibited tyrosine phosphorylation of procaspase- 8 , likely inducing its local activation, followed by downregulation of both Ret and Fap-1, and translocation of CD95 into lipid rafts. According to the resulting increase of CD95 cell surface expression, the CD95 agonist antibody CH11 enhanced RPI-1-induced cell growth inhibition and apoptosis. RET RNA interference downregulated Fap-1 protein in MZCRC-1 cells, whereas exogenous RET-M918T upregulated Fap-1 in HEK293 cells. Overall, these data indicate that the Ret oncoprotein exerts opposing controls on Fap-1 and CD95, increasing Fap-1 expression and decreasing CD95 cell surface expression. The functional interplay of the Ret mutant with the extrinsic apoptosis pathway provides a mechanism possibly contributing to MTC malignant phenotype and a rational basis for novel therapeutic strategies combining Ret inhibitors and CD95 agonists.

Keywords: RET oncogene, Medullary thyroid cancer, Fap-1, CD95, MEN2B, Caspase 8 


\section{INTRODUCTION}

Medullary thyroid carcinoma (MTC) arises from thyroid C cells [1]. It represents 5\% of thyroid cancers and may originate sporadically $(75 \%)$ or as a component of the inherited multiple endocrine neoplasia type 2 (MEN2) syndromes including MEN2A, MEN2B and familial MTC [2]. MTC, which is the most common cause of death in MEN2 patients, is relatively unresponsive to radiotherapy and conventional chemotherapy. Thyroidectomy remains the standard treatment and the only curative therapy [3]. The lack of effective treatments for unresectable, recurrent, or metastatic MTC indicates the urgent need for new therapeutic options.

Activating mutations of the RET proto-oncogene have been implicated in the pathogenesis of hereditary MTC being present in almost 100\% of MEN2A and MEN2B cases and in $30-50 \%$ of sporadic cases [4,5]. RET encodes a receptor tyrosine kinase (TK) widely expressed in neural crest-derived tissues including thyroid $\mathrm{C}$ cells. Germline RET mutations are recognized as disease causative events [6]. MEN2 is characterized by strong genotype/phenotype association, with specific RET mutations identified in each disease subtype [7]. MEN2B, the most aggressive form, is primarily associated with missense mutations in the intracellular TK domain. Most MEN2B patients harbor the M918T mutation, whereas $<5 \%$ of patients have the A883F mutation. RET M918T, which is also the most frequent somatic mutation in sporadic MTCs is prognostic of aggressive disease thus indicating a strong carcinogenic potential [3,7]. Substitution of methionine 918 with threonine results in increased Ret kinase activity, release of auto-inhibition, increased ligandindependent formation of activated monomers and dimers, and change in substrate specificity contributing to the receptor oncogenic activity [8,9]. Preclinical studies have provided evidence that Ret oncoproteins may represent a therapeutic target exploitable in subsets of thyroid tumors $[5,10,11]$. By the screening of a series of novel synthetic arylidene indolin-2- 
one compounds in a kinase assay, we identified the indolin-2-one named RPI-1 as a Ret inhibitor and reported its ability to inhibit kinase activity, expression and downstream signaling of Ret oncoproteins in thyroid cancer models $[12,13]$. The drug showed antitumor activity in mice carrying tumor xenografts from a human MTC cell line (TT) harboring the RET C634W MEN2A-type mutation [14]. Tumor regressions in treated animals were observed in association with apoptosis induction and angiogenesis inhibition [15]. Currently, several agents targeting Ret among other kinases are under clinical investigation in thyroid cancers $[3,16]$.

Proto-Ret belongs to the family of receptors defined as "dependence receptors" because they depend on their respective ligands to prevent apoptosis [17]. This group of structurally unrelated receptors shares the common feature of inducing two distinct forms of signal transduction: proliferation, survival, differentiation and migration in the presence of ligand, apoptosis in the absence of ligand. Apoptosis requires the receptor cleavage by specific caspases and the release/exposure of proapoptotic peptides [18]. The proapoptotic function is apparently lost in oncogenically activated Ret receptors, whereas recent studies suggest that they may intercept apoptotic pathways by multiple mechanisms. Indeed, either selective signaling disruption by $R E T$ dominant-negative or expression knockdown by $R E T$ siRNA induce apoptosis in TT cells $[19,20]$. We found that activation of Akt and Erks was inhibited by RPI-1 in TT cells, with the consequent activation of Bad and caspase-9, resulting in apoptosis induction through the intrinsic pathway [15]. Recently, Fas-associated phosphatase-1 (Fap-1, PTPN13) has been identified as one of the RPI-1-sensitive components in the signaling network of RET mutant-expressing MTC cells [21]. Fap-1, a large nonreceptor protein tyrosine-phosphatase (PTP), is the only protein known to associate with the C-terminal negative regulatory domain of CD95 (Fas/APO1) death receptor (DR) [22,23]. Elucidation of mechanisms and players of the cross-talk between Ret signaling and 
apoptosis pathways may provide a rational basis for the optimization of Ret-targeting approaches in MTC. The known function of Fap-1 as negative regulator of CD95 DR [24] prompted us to investigate the involvement of the extrinsic apoptosis pathway in RPI-1induced cell death. Here, we examined the role and the molecular determinants of DRmediated apoptosis in a cellular model of human MEN2B MTC, focusing on the interconnection between Ret and CD95-mediated apoptosis.

\section{MATERIALS AND METHODS}

\subsection{Chemicals and reagents}

Synthesis and chemical structure of RPI-1 (1,3-dihydro-5,6-dimethoxy-3-[(4-hydroxyphenyl) methylene]-H-indol-2-one) (Cpd1) were previously reported [12]. The agonistic anti-CD95 antibody, clone $\mathrm{CH} 11$, was purchased from MLB Co. (Nagoya, Japan). The caspase inhibitors: pan caspase inhibitor Z-VAD-FMK, caspase-8 inhibitor Z-IETD-FMK and caspase-9 inhibitor Z-LEHD-FMK were from Calbiochem (San Diego, CA). For cell treatments, RPI-1, dasatinib, sorafenib, and caspase inhibitors were dissolved in DMSO and diluted in cell culture medium (final solvent concentration 0.5\%).

\subsection{Cell culture, growth inhibition and transfection assays}

The human MTC cell lines MZ-CRC-1, harboring the MEN2B-type RET M918T mutation and TT, harboring the MEN2A-type RET C634W mutation [25] were grown in DMEM and Ham's F12 medium (Invitrogen, Carlsbad, CA), respectively, supplemented with 15\% FBS (HyClone Laboratories, Logan, UT), in a 5\% $\mathrm{CO}_{2}$ atmosphere. NIH3T3 mouse fibroblasts and $\mathrm{NIH}_{3} 3^{\mathrm{MEN} 2 \mathrm{~B}}$, stably transfected with the RET M918T mutant (short isoform), were maintained in DMEM containing 10\% and 5\% calf serum (Colorado Serum Company, 
Denver, $\mathrm{CO}$ ), respectively, in a $10 \% \mathrm{CO}_{2}$ atmosphere [26]. Human embryonic 293T cells (HEK293) were grown in DMEM supplemented with 10\% FBS and transiently transfected by calcium phosphate precipitation with $\mathrm{pRc} / \mathrm{CMV}$ expression vector carrying the insert $R E T^{\mathrm{M} 918 \mathrm{~T}}$ (short isoform) [27,28].

For cell growth inhibition assays, fibroblasts were treated with RPI-1 the day after seeding whereas MTC cells were exposed to RPI-1 4 days after plating because of their prolonged lag period. The drug antiproliferative effect was evaluated after 3 days by cell counting (fibroblasts) or after 7 days by the sulforhodamine B (SRB) colorimetric assay (MTC cells) as previously described [14]. Drug concentrations able to inhibit cell growth by $50 \%$ or by $80 \%\left(\mathrm{IC}_{50}, \mathrm{IC}_{80}\right)$ were calculated from dose-response curves. The effect of RPI1/CH11 combination treatment on cell growth was evaluated by SRB assay. Cells were incubated with RPI-1 for $96 \mathrm{~h}$ or with $\mathrm{CH} 11$ for $48 \mathrm{~h}$, alone or in combination $(\mathrm{CH} 11$ in the last $48 \mathrm{~h}$ ). Drug interactions, expressed as synergistic ratio (SR) values, were calculated according to Kern et al. [29]. SR > 1 indicates synergy; $\mathrm{SR}=1$, or $\mathrm{SR}<1$, indicates absence of synergy.

\subsection{RNA interference}

To silence RET in MTC cells, the Hs-RET-9-HP-validated siRNA from Qiagen (Santa Clarita, CA) was used. The negative control siRNA (AllStars) was from Qiagen. The oligonucleotides (final concentration $200 \mathrm{nM}$ for MZ-CRC-1 cells and 100 or $200 \mathrm{nM}$ for TT cells) were transfected into the cells using the Lipofectamine 2000 transfection reagent in serum-free Opti-MEM I (Invitrogen). Cells were incubated for 4h before complete medium addition. After $48 \mathrm{~h}$, the transfection procedure was repeated. Cells were then lysed for Western blot analysis, after additional $48 \mathrm{~h}$. 


\subsection{Biochemical analyses}

Cells were processed for total protein extraction or immunoprecipitation, followed by Western blotting, as previously described $[14,15]$. The biochemical effects of CD95 stimulation were analyzed in MZ-CRC-1 cells treated with CH11 antibody for 48h. Where indicated, cells were pre-treated with RPI-1, or vehicle, for $48 \mathrm{~h}$ before addition of the CH11 antibody. To study the effects of caspase inhibition, cells were pre-treated with $50 \mu \mathrm{M}$ caspase inhibitors for $1 \mathrm{~h}$, and then exposed to vehicle or RPI-1 for $48 \mathrm{~h}$. Cells were treated with dasatinib and sorafenib for the indicated times at the concentrations corresponding to the $\mathrm{IC}_{80}$ and/or $\mathrm{IC}_{50}$ assessed by cell counting at $72 \mathrm{~h}$.

For the isolation of lipid rafts-enriched cell fractions, cells were washed twice in icecold PBS containing sodium orthovanadate $(0.1 \mathrm{mM})$, and lysed in $1 \%$ Triton $\mathrm{X}-100$ lysis buffer as described [30]. Detergent-soluble and -insoluble (enriched in lipid rafts) fractions were separated by centrifugation (10000 x g for $15 \mathrm{~min})$. Equal volumes of each fraction were analyzed by Western blotting.

Mouse monoclonal antibodies used were: anti-phosphotyrosine, clone 4G10, from Upstate Biotechnology (Lake Placid, NY); anti-PKB $\alpha /$ Akt from Transduction Laboratories (Lexington, KY); anti- $\beta$-tubulin from Sigma Chemical Company (St. Louis, MO); anti-Flip from Alexis Biochemicals (San Diego, CA); anti-caspase-8 from Cell Signaling Technology (Beverly, MA). Rabbit polyclonal antibodies used were: anti-Ret (H-300), anti-caspase-9 (H83) and anti-FAP-1 (H-300), anti-HSP90 $\alpha / \beta$ (H-114), anti-phospho-Ret (Y1062) from Santa Cruz Biotechnology (Santa Cruz, CA); anti-cleaved caspase-3, anti-phospho-p44/42 ERKs (T202, Y204), anti-phospho-Akt (S473), anti-cleaved poly(ADP-ribose) polymerase, antiphospho-Src (Y416), anti-Src, and anti- FADD from Cell Signaling Technology; anti-caspase8 from BD Pharmingen (Franklin Lakes, NJ); anti-p44/42 ERKs from Upstate Biotechnology; anti-actin from Sigma. The goat polyclonal antibody anti-TRAIL-R1 (DR4) was obtained 
from R\&D System (Abingdon, UK).

Densitometric analysis of blots was done by the Quantity One 4.6.3 software (BioRad, Hercules, CA). Signal intensities were determined using volume analysis with local background correction. Band values were normalized versus the calculated amount of tubulin in the same samples.

\subsection{Apoptosis and caspase activity detection}

Apoptosis was assessed by the terminal deoxynucleotidyl transferase-mediated deoxyuridine triphosphate nick-end labeling (TUNEL) assay as previously described [15]. Apoptosis in the presence of $\mathrm{CH} 11$ antibody was assayed by Cell Death Detection Elisa Plus Kit (Roche Diagnostic GmbH, Manheim, Germany) according to the manufacturer instructions. Cytoplasmic histone-associated DNA fragmentation was corrected for protein content evaluated by SRB assay performed in parallel. The catalytic activity of caspase- 3 , caspase- 8 , and caspase- 9 was determined as the ability to cleave the fluorogenic substrates $N$-acetyl-AspGlu-Val-Asp-AMC (DEVD-AMC), $\mathrm{N}$-acetyl-Ile-Glu-Thr-Asp-AMC (IETD-AMC) and $\mathrm{N}$ acetyl-Leu-Glu-His-Asp-AMC (IETD-AMC), respectively, by means of the specific Apopcyto caspase assay kits (MBL). The hydrolysis of the specific substrates by the different caspases was monitored by spectroflurometry with $380-\mathrm{nm}$ excitation and 460-nm emission filters.

\subsection{Confocal laser microscopy and FACS analysis}

For confocal immunofluorescence analysis, cells grown on glass coverslips were permeabilized and fixed in methanol/glacial acetic acid (3:1) for $5 \mathrm{~min}$, then washed in PBS. Unspecific binding sites were blocked with $1 \%$ BSA in PBS for $30 \mathrm{~min}$. Cells were then incubated with goat anti-Ret (C-20, 1:200) or rabbit anti-Fap1 (H-300, 1:100) antibodies 
(Santa Cruz Biotechnology) for $1 \mathrm{~h}$ at room temperature. After washing in PBS, cells were incubated with anti-goat Alexa Fluor 546 or anti-rabbit Alexa Fluor 488 antibodies (Invitrogen), diluted 1:1000, for $30 \mathrm{~min}$ at room temperature. Confocal laser scanning analysis was carried out with a Microradiance 2000 laser scanning microscope (Bio-Rad Laboratories, Inc., Hercules, CA) equipped with Ar (488 nm), HeNe $(593 \mathrm{~nm})$ and Red $(637 \mathrm{~nm})$ diode lasers. Images (512X512 pixels) were obtained with $60 \mathrm{X}$ objective and analyzed using ImagePro 6.3 software. For fluorescence-activated cell sorter (FACS) analysis of CD95 cell surface expression, cells were incubated with $1 \%$ BSA in PBS for $45 \mathrm{~min}$, and then with rabbit anti-CD95 antibody (FL335, Santa Cruz Biotechnology, 1:50) for $1 \mathrm{~h}$, followed by Alexa Fluor 488 goat anti-rabbit $\operatorname{IgG}(1: 500)$ for $30 \mathrm{~min}$ at room temperature. Cells were then washed in PBS and analyzed by flow cytometer FACSCalibur (Becton Dickinson, San Jose, CA). Dead cells were gated out by forward and side light scattering.

\subsection{Antitumor activity}

In vivo experiments were performed using 8-11-week-old female SCID mice (CB17/ICR$\operatorname{Prkdc}^{\mathrm{SCID}} / \mathrm{Crl}$ by Charles River, Calco, Italy). Experimental protocols were approved by the Ethics Committee for Animal Experimentation of the Fondazione IRCCS Istituto Nazionale dei Tumori (Milan, Italy), according to the United Kingdom Coordinating Committee on Cancer Research Guidelines [31]. Experimental groups included 5 to 10 mice. Exponentially growing MZ-CRC-1 cells $\left(2.8 \times 10^{7}\right)$ were injected s.c. and tumor growth was followed by biweekly tumor diameter measurements using a Vernier caliper. Tumor weight (TW) was calculated according to the formula: TW $(\mathrm{mg})=$ tumor volume $\left(\mathrm{mm}^{3}\right)=\mathrm{d}^{2} \times \mathrm{D} / 2$, where $d$ and $D$ are the shortest and the longest diameter, respectively. Treatments with RPI- 1 started 5 days after tumor cell inoculum, when TW was approximately $70 \mathrm{mg}$. The drug was dissolved in vehicle (polisorbate 80: ethanol: distilled water, 20:8:72 v:v:v) and was delivered orally, by 
gavage, at the dose of 100 or $150 \mathrm{mg} / \mathrm{kg}$, bis in die (BID) for 45 days. Control mice were treated with vehicle. The efficacy of drug treatment was assessed as TW inhibition percent (TWI\%) in drug-treated versus control mice expressed as TWI\% $=100-($ mean TW treated $/$ mean TW control x 100). Drug tolerability was assessed as body weight loss percent during treatment and lethal toxicity (i.e., any death in treated groups occurring before any death in the control group).

\subsection{Statistics}

Statistical analyses by 2-tailed Student's $t$ test, or Mann-Whitney test for in vivo experiments, were performed using the GraphPad Prism software, version 4.0 (GraphPad Prism Inc., San Diego, CA). P values lower than 0.05 were considered significant.

\section{RESULTS}

3.1. RPI-1 inhibits Ret-MEN2B transforming activity in NIH3T3 cells and induces apoptosis in MTC cells through the extrinsic pathway

In a preliminary set of experiments, the biochemical and biological effects of Ret inhibition were examined in NIH3T3 $3^{\mathrm{MEN} 2 \mathrm{~B}}$ transfectants harboring the RET MEN2B-type mutation M918T. Upon treatment with the Ret inhibitor RPI-1, cell growth inhibition $\left(\mathrm{IC}_{50}=4.7 \pm 0.2\right.$ $\mu \mathrm{M})$ was associated with reduction of Ret tyrosine phosphorylation/expression and with stable reversion of the transformed cell morphologic phenotype (Supplementary Figures S1 A and B). Drug-induced abrogation of Ret tyrosine phosphorylation and downregulation of Ret expression were then confirmed in the human MTC cell line MZ-CRC-1 expressing endogenous RET M918T (Fig. 1A). A strong reduction of activating phosphorylations in either ERKs or AKT in treated cells also indicated the downmodulation of the Ras/ERK and PI3K/AKT proliferation/survival pathways, both described as highly activated by the Ret 
M918T mutant [10]. Cell treatment in a range of RPI-1 concentrations active against the Ret kinase inhibited cell growth in a dose-dependent way (Fig. 1B).

Drug treatment also showed efficacy in in vivo experiments (Fig. 1C). In fact, upon oral administration at 100 or $150 \mathrm{mg} / \mathrm{kg}$, BID for 45 days in mice bearing subcutaneous MZCRC-1 xenografts, tumor growth inhibition was maintained during the treatment period (TWI at day $36=76 \%$ in both treated groups, $\mathrm{P}<0.002$ and $\mathrm{P}<0.005$, respectively). One week after treatment end, inhibition reached $72 \%$ and $75 \%(\mathrm{P}<0.005$ and $\mathrm{P}<0.01$ vs controls) with the doses 100 and $150 \mathrm{mg} / \mathrm{kg}$, respectively, without evidence of toxicity.

MZ-CRC-1 cells treated with RPI-1 were then examined to assess apoptosis. Fig. 2A shows dose-dependent apoptosis measured by TUNEL staining. As previously described in MEN2A-type MTC cells (TT) [15], RPI-1-induced apoptosis was caspase-dependent. In fact, caspase- 3 and, to a lesser extent, caspase- 9 activation was detected by enzyme assays in a dose- and time-dependent way (Fig. 2B). Noteworthy, drug-treated MZ-CRC-1 cells, also showed a significant activation of caspase- 8 , the main initiator caspase of the extrinsic apoptosis pathway.

\subsection{CD95 apoptotic signal is potentiated by RPI-1 treatment in MEN2B-type MTC cells}

The CD95 DR inhibitor Fap-1 has been previously implicated in the signaling network sensitive to RPI-1 in MTC cells [27], and caspase-8 activation in MZ-CRC-1 cells suggested the engagement of DR-mediated apoptosis. Thus, we focused our investigation on the drug effects on CD95 cell death pathway. CD95-mediated signaling involves its translocation into lipid rafts even in the absence of the CD95 ligand [32]. In such functional microdomains, the formation of the death-inducing signaling complex (DISC) allows recruitment and autocatalytic processing of procaspase-8 [33]. To explore signaling events involved in RPI-1induced activation of this pathway, we examined the distribution of DISC components in cell 
fractions insoluble in Triton X-100, typically enriched in lipid rafts [34]. CD95 showed a prevalent localization in the Triton X-100-soluble fraction of MZ-CRC-1 cells in basal conditions (Fig. 3A). Treatment with RPI-1 $(60 \mu \mathrm{M}, 96 \mathrm{~h})$ induced a complete translocation of CD95 to the insoluble fraction suggesting its recruitment into the DISC; consistently, the adaptor molecule Fas-associated protein with death domain (FADD) and procaspase-8 translocated from the soluble to the insoluble fraction after drug treatment. By contrast, the constitutive localization in the insoluble fraction of the cellular FLICE-inhibitory protein (cFLIP $_{\mathrm{L}}$ ), an endogenous caspase-8 antagonist, was not affected by drug treatment.

Next, we examined whether RPI-1 treatment could enhance exogenous stimulation of CD95 sensitizing cells to CD95-mediated apoptosis. A partial re-localization of CD95 and procaspase-8 into the detergent-insoluble fraction was observed in cells stimulated with the anti-CD95 agonist monoclonal antibody CH11 $(300 \mathrm{ng} / \mathrm{ml})$. A similar re-distribution of the two apoptosis effectors was observed in cells treated with $30 \mu \mathrm{M}$ RPI-1. However, the relocalization of both CD95 and procaspase- 8 was dramatically enhanced in cells exposed to the combined CH11/RPI-1 treatment, with a complete translocation to the lipid rafts-enriched fraction (Fig. 3B). At variance, the distribution of the TNF-related apoptosis inducing ligand receptor DR4, which also signals apoptosis through the extrinsic pathway [35], and that of cFLIP $_{\mathrm{L}}$ were not modulated by treatments. Fap-1, a CD95-binding protein not participating to the DISC [24], maintained its prevalent distribution in the soluble fraction. Interestingly, it disappeared in cells receiving the combined treatment (Fig. 3B). Cell growth and apoptosis were then analyzed in cells exposed to the two agents (Figures 3C and 3D). Whereas CH11 alone induced only a slight reduction of cell growth, the combination with RPI-1 produced a superadditive/synergistic interaction $(\mathrm{SR}=1.2$ and 2.1 in treatments combining $300 \mathrm{ng} / \mathrm{ml}$ CH11 with $15 \mu \mathrm{M}$ and $30 \mu \mathrm{M}$ RPI-1, respectively) (Fig. 3C). Likewise, the pro-apoptotic effect of the two agents was potentiated, as indicated by cell death assay (Fig. 3D) and by the 
biochemical analysis showing increased cleavage of caspases and PARP, a substrate of executioner caspases, as compared to single agent treatments (Fig. 3E and Supplementary Fig. S2).

\subsection{RPI-1 treatment downregulates Fap-1 and upregulates cell surface CD95 in MZ-CRC-1 cells}

The PTP Fap-1 is known to act as a negative switch in the CD95 pathway by binding CD95 in intracellular compartments and preventing its localization at the cell surface [24]. Changes in the levels of endogenous Fap-1 can modulate CD95 cell surface expression [36]. Since Fap-1 levels in MZ-CRC-1 cell fractions appeared lowered by treatment with RPI-1 alone, and abolished by co-treatment with CH11 (Fig. 3B), we further investigated the relationship between the drug effects on Fap-1 cellular levels and apoptosis induction. In time-course experiments, Fap-1 levels decreased after RPI-1 treatment $(60 \mu \mathrm{M})$ beginning at around 48h, and disappearing by $72 \mathrm{~h}$ (Fig. 4A). A similar kinetics was observed for the cleavage of caspase-3 and PARP, indicating that Fap-1 downregulation paralleled apoptosis execution. Unexpectedly, cleaved forms of caspase- 8 appeared earlier, being already detectable after $6 \mathrm{~h}$ of RPI-1 treatment. A similar kinetics was observed for the downregulation of signaling pathways downstream of Ret as indicated by the abrogation of activating phosphorylations of AKT and ERKs (Fig. 4A).

The biochemical and biological effects associated with Ret inhibition shown so far were consistent with the induction of CD95-mediated apoptosis promoted by the removal of the negative constraint exerted by Fap-1 on CD95. To test this hypothesis by an independent approach, we determined CD95 cell surface expression by FACS analysis (Fig. 4B). MZCRC-1 cells showed low surface CD95 levels in basal conditions, however, CD95 immunodetection increased in a dose-dependent way, beginning around $72 \mathrm{~h}$ after RPI-1 
treatment. These findings confirmed that drug-induced downregulation of Fap-1 was reflected in the upregulation of CD95 at the cell surface.

\subsection{Fap-1 levels are regulated by Ret-MEN2B through a molecular interaction}

To test further the connection between Ret inhibition, Fap-1 downregulation, and CD95-mediated apoptosis in MZ-CRC-1 cells, we used another Ret kinase inhibitor, sorafenib, structurally unrelated to RPI-1 [37]. Indeed, cell treatment with sorafenib ( IC $_{50}$, for 24 and 48 h) downregulated Ret as previously reported [38] and this effect was consistently associated with Fap-1 downregulation and caspase-8 activation (Supplementary Fig. S3A).

Then, to get insight into the functional interplay of Ret with Fap-1, we performed RNA interference and transfection experiments. As shown in Fig. 5A, siRNA-mediated RET silencing in MZ-CRC-1 cells resulted in a remarkable reduction of Ret protein expression which was reflected in a marked downregulation of Fap-1 protein levels. Similar results were obtained in the MTC cell line TT harboring the MEN2A-type C634W RET mutant, indicating that the inhibitory effect of RET silencing on Fap-1 protein expression was not restricted to the MZ-CRC-1 MTC model (Supplementary Fig. 3B). We next performed transient transfections with expression plasmids encoding the RET-MEN2B mutant M918T in HEK293 cells which do not express detectable levels of endogenous Ret but express low levels of Fap1. Cell lysates were analyzed for vector expression and Fap-1 levels $48 \mathrm{~h}$ after transfection (Fig. 5B). Phosphorylation of Ret Tyr1062, the docking site controlling most of Retdependent signaling, was also detected to assess the activation state of the expressed RetMEN2B protein. Ret-MEN2B was highly and dose-dependently expressed in transfected cells, showing also elevated phosphorylation levels. In agreement, its constitutive activation was reflected in increased phosphorylation of ERKs. Cells expressing the Ret mutant showed higher levels of Fap-1 as compared to the parental cells (Fig. 5B). These data indicated that 
endogenous Fap-1 is likely stabilized by Ret mutant expression in MTC cells.

A possible interaction between the two molecules was explored by coimmunoprecipitation experiments. Fig. 5C shows that tyrosine phosphorylated Fap-1 was coimmunoprecipitated with Ret from untreated MZ-CRC-1 cells. Reciprocal coimmunoprecipitation confirmed the molecular interaction of Ret with Fap-1. As expected, a 24 h-treatment with RPI-1 (60 $\mu \mathrm{M})$ abrogated tyrosine phosphorylation of Ret and markedly downregulated its expression. Tyrosine phosphorylation of the Fap-1 was also decreased in treated cells as expected [27], although its binding to Ret was scarcely affected after $24 \mathrm{~h}$ of exposure to the drug. The persistence of the Ret-Fap-1 binding in treated cells suggested that the interaction between the two proteins was independent of Ret overall tyrosine phosphorylation.

Having established that Ret and Fap-1 are present in a molecular complex in MZCRC-1 cells, we analyzed their sub-cellular distribution by confocal microscopy after double labeling with specific antibodies. Indirect immunofluorescence staining revealed a similar dotted distribution of the two proteins throughout the cell (Fig. 5D). Merging of the two fluorescence signals showed partial co-localization thereby confirming that the two proteins can be found in the same intracellular compartments.

\subsection{Role of caspases in RPI-1-induced downregulation of Fap-1 and Ret}

We sought to investigate the mechanism leading to the downregulation of both Ret and Fap-1 in MZ-CRC-1 cells exposed to RPI-1. Our data showed that drug treatment induced an early caspase- 8 activation which preceded the occurrence of Fap- 1 downregulation and the increase in CD95 cell surface expression (Fig. 4). Moreover, we observed that although cell treatment with $\mathrm{CH} 11$ was able to enhance Fap-1 downregulation in the presence of RPI-1, treatment with the CD95 agonist antibody alone did not affect Fap-1 protein levels (Fig. 6A). These 
findings suggested that caspases, in particular caspase-8, might play a role also in events occurring before CD95 engagement, and confirmed that Fap-1 level decrease required Ret inhibition.

To investigate the role of caspases in RPI-1-induced downregulation of both Fap-1 and Ret, MZ-CRC-1 cells were treated with the drug in the presence of caspase inhibitors. Fap-1 downregulation induced by 48 h-treatment with RPI-1 was abolished by the caspase- 8 inhibitor peptide Z-IETD, as well as by the caspase-9 inhibitor Z-LEHD, or by the broadspectrum inhibitor Z-VAD (Fig. 6B). A distinct pattern of sensitivity to caspase action was displayed by Ret, which was still fully downregulated by RPI-1 treatment in the presence of Z-VAD and partially downregulated in the presence of the caspase- 8 or -9 inhibitors. In these experimental conditions, Z-VAD inhibited the full cleavage of caspase-3 and completely abrogated PARP cleavage, thereby confirming the blockade of caspase executioners of apoptosis. In contrast, both Z-IETD and Z-LEHD induced only partial inhibition of caspase-3 and PARP cleavage (Fig. 6B). These findings showed that whereas several caspases, including caspase-3, -8 and -9 , may contribute to Fap-1 downregulation induced by RPI-1, Ret downregulation is at least partially dependent on the activity of initiator caspases 8 and 9 but not of executioner ones such as caspase-3.

\subsection{RPI-1 treatment induces early local activation of Ret-associated caspase-8 independent} of $\operatorname{Src}$

The caspase-dependent downregulation of Ret induced by RPI-1 (Fig. 6B) reminded the dependence receptor function of Ret. A possible interaction of Ret with caspase- 8 in MZCRC-1 cells was analyzed by immunoprecipitation experiments. Procaspase-8 was coimmunoprecipitated with Ret from either treated (60 $\mu \mathrm{M}$ RPI-1, for $6 \mathrm{~h})$ or untreated MZCRC-1 cells (Fig. 6C). The immuno-precipitates also included Src, a known Ret-binding 
signaling molecule and modulator of caspase- 8 activation [12,39], whereas procaspase-3, or DISC components such as FADD or c-FLIP were absent (not shown). The presence of procaspase- 8 in immuno-complexes containing Ret and Src tyrosine kinases prompted us to analyze the zymogen phosphorylation status in MZ-CRC-1 cells. In fact, tyrosine phosphorylation has been reported to play a role in the control of procaspase- 8 processing by inhibiting its proteolytic activation [40]. Immunoprecipitation with anti-phosphotyrosine antibody revealed the procaspase basal tyrosine phosphorylation which was reduced by RPI-1 treatment in a dose-dependent way (Fig. 6D). Moreover, this effect paralleled the zymogen cleavage. Procaspase- 8 co-immunoprecipitated with Ret was also tyrosine phosphorylated (Supplementary Fig. S4A). Both RPI-1 and dasatinib, a TK inhibitor known to target Src [41] but not directly active on Ret (data not shown), were able to inhibit tyrosine phosphorylation of the Ret-bound zymogen. However, the effect of the Src inhibitor was not associated with early (6h) caspase-8 activation (Supplementary Fig. S4A), or with Ret and Fap-1 downregulation and PARP cleavage at later times (24-48 h) (Supplementary Fig. S4A, B). These effects were thus plausibly induced by RPI-1 as a consequence of Ret inhibition.

\section{DISCUSSION}

The present study describes for the first time the cross-talk between a Ret oncoprotein responsible for development of inherited MEN2B syndrome and players of the extrinsic apoptosis pathway. In the context of a study exploring the therapeutic opportunity of targeting Ret in MEN2B-type MTC, we found that oral treatment of mice bearing subcutaneous xenograft tumors of the human MTC cell line MZ-CRC-1, carrying endogenous RET M918T mutation, with the Ret TK inhibitor RPI-1, resulted in a remarkable antitumor activity. Investigation of cellular effects indicated that drug treatment induced apoptosis through the 
CD95 DR pathway. Our data showed that the RET mutant was able to regulate protein levels of the PTP Fap-1, a major negative regulator of CD95, likely through its stabilization. Ret formed a complex with Fap-1 and with zymogenic caspase-8. Targeting of Ret with RPI-1 resulted in inhibition of procaspase- 8 tyrosine phosphorylation and its early local activation followed by downregulation of both Ret and Fap-1, and CD95 engagement to apoptosis.

Our data support a role of Fap-1 as a mediator of the cross-talk between Ret signaling and the CD95 pathway in MZ-CRC-1 cells. Fap-1 is a cytoplasmic PTP characterized by the presence of multiple protein-protein interaction motifs, including five PDZ domains, which allow it to function as a scaffold protein directing the assembly of macromolecular signaling complexes. Besides CD95, which can bind two PDZ domains, several signaling proteins have been described as Fap-1-binding proteins including HER2, IRS-1, STAT4, Ephrin B1, IkB $\alpha$, and $\mathrm{p} 75^{\mathrm{NTR}}$ [42]. We show here that Ret co-localized with Fap-1 and the two proteins were co-immunoprecipitated from MZ-CRC-1 cells. Although our data do not allow for definitely establishing whether Ret binds Fap-1 directly, this hypothesis is suggested by the presence at the cytoplasmic tail of Ret of a sequence, Ser-Pro-Val, previously shown to be involved in the interaction between a PDZ domain of Fap-1 and p $75^{\mathrm{NTR}}$. Moreover, the Ret sequence Ser-TyrVal, containing the autophosphorylation residue Tyr905, is also consistent with the canonical PDZ motif S/T-X-V [43].

Fap-1 is expressed at high levels in several tumor types [36]; its implication in cancer is complex and context-dependent being reported as either a tumor promoting or a tumor suppressor in different studies $[23,42,44]$. Interestingly, the recent identification of Fap-1 as a target of the epithelial-to-mesenchymal transition regulator miR-200c, which is lost during cancer progression, provides a mechanistic explanation for the early loss of sensitivity of cancer cells to CD95-mediated apoptosis during neoplastic transformation [45]. Our data support an anti-apoptotic role for Fap-1 in the context of MTC. Indeed, in MZ-CRC-1 cells 
the Fap-1 function as inhibitor of the CD95 trafficking to the cell surface appeared to be controlled by Ret. In fact, disruption of the complex formed by Ret and Fap-1, following Ret inhibition, resulted in the upregulation of CD95 cell surface expression and ligandindependent apoptosis which could be further enhanced by the CD95 agonist antibody CH11. Most likely, various mechanisms can contribute to upregulate Fap-1 in different tumor types [44]. In Ewing's sarcomas, identification of Fap-1 as a transcriptional target for the oncogenic fusion protein EWS-FLT1 directly implicated Fap-1 in tumorigenesis [42]. In MZ-CRC-1 MTC cells, Fap-1 did not seem to be regulated by Ret at the transcriptional level since Fap-1 mRNA levels were not significantly reduced by RPI-1 treatments abrogating Ret expression in time-course experiment up to $96 \mathrm{~h}$ (not shown). Based on evidence that both proteins were subjected to caspase degradation following Ret inhibition, it is conceivable that engagement in a molecular complex with Ret might reduce proteolytic degradation of Fap-1, which is a labile protein in physiological conditions [46]. In agreement with this hypothesis, silencing of RET in the MTC cell lines MZ-CRC-1 or TT resulted in downregulation of Fap-1, whereas exogenous expression of RET-MEN2B in HEK293 cells increased Fap-1 protein levels. Fap-1 stabilization might thus provide a mechanism contributing to survival in RET mutantexpressing MTC cells. Although our study suggests that Fap-1 associates with Ret independently of Ret tyrosine phosphorylation, additional studies are needed to establish whether the Ret-Fap-1 interaction is regulated by reciprocal phosphorylation/dephosphorylation on specific tyrosine residues. The interaction between Ret and Fap-1 described in this study is in line with emerging evidence suggesting that a bidirectional communication between caspases and protein kinases/phosphatases contributes to the control of cell survival and cell death [47]. The cross-talk between these enzymes would normally allow for the fine tuning of the apoptotic threshold in response to alterations in the cellular environment. Consistently, cell transformation, which is often associated with 
deregulation of the survival/apoptosis balance on favor of survival, frequently involves protein kinases and phosphatases.

Proto-Ret is known as a "dependence receptor" inducing, in the absence of ligand, an active pro-apoptotic signal dependent on the receptor proteolytic processing by caspase activation [17]. Dependence receptors are structurally different but functionally related receptors involved in neuronal development and survival [48]. Notably, the interaction with Fap-1 is shared with another dependence receptor, the neutrophin receptor p $75^{\mathrm{NTR}}$ [49], thus suggesting that Fap-1 may be a common partner used by these receptors to regulate apoptosis. It remains poorly understood how the dependence receptor proapoptotic function is evaded by oncogenic Ret mutants. It has been postulated that the mutant receptor is "stuck" in the "off" position with respect to cell death induction, rendering cells insensitive to the lack of ligand availability [50]. The results reported here suggest that the "on" position for apoptosis induction may be restored by targeting Ret in MEN2B-type MTC cells. Activation of the caspase-8 pro-enzyme associated with the Ret mutant may be the initial event unlocking the dependence receptor function as endogenous caspase amplifier. In RPI-1-treated MZ-CRC-1 cells, caspase- 8 activation preceded by several hours caspase-3 activation. Indeed, we found that RPI-1-induced downregulation was at least partially dependent on caspase-8 enzyme activity. Procaspase-8 was co-immunoprecipitated with Ret. Moreover, Ret harbors a number of non-canonical and canonical caspase substrate cleavage sites including the known DEXD sequence required by caspase-8 [50] (www.casbase.org/casvm/index.html). It is worthy of note that in contrast with the proteolytic process of proto-Ret activated following GDNF deprivation [17], proteolysis of the Ret-MEN2B-type mutant likely does not involve caspase3.

A general open question in apoptosis induced by dependence receptors concerns the initiation mechanisms [50]. We showed that procaspase-8 in MZ-CRC-1 cells, including that 
associated with Ret, was tyrosine phosphorylated and treatment with RPI-1 strongly reduced this phosphorylation. It is tempting to speculate that Ret kinase inhibition might trigger local caspase- 8 activation and the consequent Ret processing. These results are reminiscent of cell death mediated by the $\alpha_{v} \beta_{3}$-integrin, another dependence receptor, which depends upon the ability of the integrin $\beta$ subunit to recruit and activate locally caspase- 8 in a DR-independent manner [50,51]. Our data also indicated that caspase- 8 activation by RPI-1 could not be ascribed to the direct or indirect inhibition of Src, although phosphorylation of caspase- 8 by Src was previously reported as inhibitory of the caspase proapoptotic function [39]. In addition, the data indicate that the local caspase- 8 activation induced by Ret targeting is not sufficient to activate apoptosis. Rather, it appears to provide the initial event triggering a cascade of selective proteolytic processes, involving Ret and Fap-1, which eventually allows, several hours later, CD95 redistribution at the cell surface. The latter is regarded as a selfsufficient event able to induce ligand-independent apoptosis or to decrease the threshold required to induce apoptosis by altering the balance between positive and negative (e.g. cFLIP) molecules participating to the DISC $[52,53]$.

Collectively, our data support a hypothetical model in which Ret-MEN2B signaling and CD95-mediated apoptosis pathway cross-talk through Fap-1. According to this model, Ret forms a complex with both Fap-1 and procaspase-8. Ret kinase inhibition induces a sequence of events including: 1) inhibition of tyrosine phosphorylation and local activation of the associated zymogenic caspase; 2) Ret proteolytic processing (and possibly caspase amplification); 3) Fap-1 destabilization and proteolytic degradation; 4) CD95 release and engagement to lipid rafts; 5) ligand-independent CD95-mediated apoptosis.

The findings reported in this study reveal previously unrecognized aspects of Ret molecular interactions which may potentially contribute to the malignant phenotype and provide the basis for novel therapeutic strategies in MEN2B-type MTC. The ability of Ret- 
MEN2B to exert a control on the cell surface expression of CD95 represents a mechanism whereby the oncoprotein can interfere with the extrinsic apoptosis pathway in MTC cells and may have a role in important steps of cancer development and progression such as immune escape [54] and resistance to apoptotic stimuli including chemotherapy [45,55]. The regulatory mechanisms described here may hold even a wider relevance since a possible role of RET is emerging in malignant tumors other than thyroid cancer [11]. Moreover, the same cross-talks can be shared by different receptor tyrosine kinases [56].

Multi-target therapeutics including Ret inhibitors have recently entered clinical trials showing significant activity in patients with MTC [3]. Noteworthy, we found that one of these agents, sorafenib [38], showed effects on the Ret /Fap-1 system comparable to those described for RPI-1. Although available reports from clinical trials hold promise, currently none of the tested mono-therapies appears to be curative, thus emphasizing the need for additional novel strategies to improve clinical responses. In conclusion, the results of the present study, showing that Ret inhibition enhances susceptibility to CD95-mediated apoptosis in MEN2Btype MTC cells, suggest that combinatorial approaches with CD95 agonists warrant further investigation.

\section{ACKNOWLEDGEMENTS}

The authors wish to thank Marco Folini and Marzia Pennati for helpful suggestions, Andrea Vecchi for FACS data analysis, and Laura Zanesi for help in editing the manuscript. The study is supported in part by Associazione Italiana per la Ricerca sul Cancro, by Progetto Strategico Istituzionale Fondazione IRCCS INT (PSI 5x1000, 2008), and by Alleanza Contro il Cancro. 


\section{REFERENCES}

[1] Hubner RA, Houlston RS. Molecular advances in medullary thyroid cancer diagnostics. Clin Chim Acta 2006; 370:2-8.

[2] Lodish MB, Stratakis CA. RET oncogene in MEN2, MEN2B, MTC and other forms of thyroid cancer. Expert Rev Anticancer Ther 2008; 8:625-32.

[3] Cakir M, Grossman AB. Medullary thyroid cancer: molecular biology and novel molecular therapies. Neuroendocrinology 2009; 90:323-48.

[4] Nikiforova MN, Nikiforov YE. Molecular genetics of thyroid cancer: implications for diagnosis, treatment and prognosis. Exp Rev Mol Diagn 2008; 8:83-95.

[5] Drosten M, Putzer BM (2006). Mechanisms of disease: cancer targeting and the impact of oncogenic RET for medullary thyroid carcinoma therapy. Nature Clin Pract 2006; 3:564-74.

[6] Santoro M, Carlomagno F, Romano A, Bottaro DP, Dathan NA, Grieco M, et al. Activation of RET as a dominant transforming gene by germline mutations of MEN2A and MEN2B. Science 1995; 267:381-3.

[7] Raue F, Frank-Raue K. Update multiple endocrine neoplasia type 2. Fam Cancer 2010; 9:449-57.

[8] Liu X, Vega QC, Decker RA, Pandey A, Worby CA, Dixon JE. Oncogenic RET receptors display different autophosphorylation sites and substrate binding specificities. J Biol Chem 1996; 271:5309-12.

[9] Gujral TS, Singh VK, Jia Z, Mulligan LM. Molecular mechanisms of RET receptormediated oncogenesis in multiple endocrine neoplasia 2B. Cancer Res 2006; 66:10741-9.

[10] Kodama Y, Asai N, Kawai K, Jijiwa M, Murakumo Y, Ichihara M, et al. The RET proto-oncogene: a molecular therapeutic target in thyroid cancer. Cancer Sci 2005; 96:143-8.

[11] Lanzi C, Cassinelli G, Nicolini V, Zunino F. Targeting RET for thyroid cancer therapy. Biochem Pharmacol 2009; 77:297-309.

[12] Lanzi C, Cassinelli G, Pensa T, Cassinis M, Gambetta RA, Borrello MG, et al. Inhibition of transforming activity of the ret/ptc1 oncoprotein by a 2 -indolinone derivative. Int J Cancer 2000; 85:384-90.

[13] Lanzi C, Cassinelli G, Cuccuru G, Zaffaroni N, Supino S, Vignati S, et al. Inactivation of Ret/Ptc1 oncoprotein and inhibition of papillary thyroid carcinoma cell proliferation by indolinone RPI-1. Cell Mol Life Sci 2003; 60:1449-59. 
[14] Cuccuru G, Lanzi C, Cassinelli G, Pratesi G, Tortoreto M, Petrangolini G, et al. Cellular effects and antitumor activity of RET inhibitor RPI-1 on MEN2A-associated medullary thyroid carcinoma. J Natl Cancer Inst 2004; 96:1006-14.

[15] Petrangolini G, Cuccuru G, Lanzi C, Tortoreto M, Belluco S, Pratesi G, et al. Apoptotic cell death induction and angiogenesis inhibition in large established medullary thyroid carcinoma xenografts by Ret inhibitor RPI-1. Biochem Pharmacol 2006; 72:405-14.

[16] Sherman SI. Targeted therapy of thyroid cancer. Biochem Pharmacol 2010; 80:592601.

[17] Bordeaxu M-C, Forcet C, Granger L, Corset V, Bidaud C, Billaud M, et al. The RET proto-oncogene induces apoptosis: a novel mechanism for Hirschsprung disease. EMBO J 2000; 19:4056-63.

[18] Mehlen P, Thibert C. Dependence receptors: between life and death. Cell Mol Life Sci 2004; 61:1854-66.

[19] Drosten M, Hilken G, Bockmann M, Rödicker F, Mise N, Cranston AN, et al. Role of MEN2A-derived RET in maintenance and proliferation of medullary thyroid carcinoma. $\mathrm{J}$ Natl Cancer Inst 2004; 96:1231-9.

[20] Koga K, Hattori Y, Komori M, Narishima R, Yamasaki M, Hakoshima M, et al. Combination of RET siRNA and irinotecan inhibited the growth of medullary thyroid carcinoma TT cells and xenografts via apoptosis. Cancer Sci 2010; 101:941-7.

[21] Gorla L, Mondellini P, Cuccuru G, Miccichè F, Cassinelli G, Cremona M, et al. Proteomics study of medullary thyroid carcinomas ex pressing RET germ-line mutations: identification of new signaling elements. Mol Carcinog 2009; 48:220-31.

[22] Abaan OD, Levenson A, Khan O, Furth PA, Uren A, Toretsky JA. PTPL1 is a direct transcriptional target of EWS-FLI1 and modulates Ewing's sarcoma tumorigenesis. Oncogene $2005 ; 24: 2715-22$.

[23] Freiss G, Chalbos D. PTPN13/PTPL1: an important regulator of tumor aggressiveness. Anti-Cancer Agents Med Chem 2011; in press.

[24] Gloire G, Charlier E, Piette J. Regulation of CD95/APO-1/Fas-induced apoptosis by protein phosphatases. Biochem Pharmacol 2008; 76:1451-8.

[25] Cooley LD, Elder FFB, Knuth A, Gagel RF. Cytogenetic characterization of three human and three rat medullary thyroid carcinoma cell lines. Cancer Genet Cytogenet 1995; 80:138-49.

[26] Bongarzone I, Monzini N, Borrello MG, Carcano C, Ferraresi G, Arighi E, et al. Molecular characterization of a thyroid tumor-specific transforming sequence formed by the 
fusion of ret tyrosine kinase and the regulatory subunit RI alpha of cyclic AMP-dependent protein kinase A. Mol Cell Biol 1993; 13:358-66.

[27] Gorla L, Cantù M, Miccichè F, Patelli C, Mondellini P, Pierotti MA, et al. RET oncoproteins induce tyrosine phosphorylation changes of proteins involved in RNA metabolism. Cell Signal 2006; 18:2272-82.

[28] Cranston, A., Carniti, C., Martin, S., Mondellini, P., Hooks, Y., Leyland, J., et al. A novel activating mutation in the RET tyrosine kinase domain mediates neoplastic transformation. Mol Endocrinol 2006; 20:1633-43.

[29] Kern DH, Morgan CR, Hildebrand-Zanki SU. In vitro pharmacodynamics of 1- $\beta$-Darabinofuranosylcytosine: synergy of antitumor activity with cisdiamminedichloroplatinum(II). Cancer Res 1988; 48:117-21.

[30] Bagnoli M, Balladore E, Luison E, Alberti P, Raspagliesi F, Marcomini B, et al. Sensitization of p53-mutated epithelial ovarian cancer to CD95-mediated apoptosis is synergistically induced by cisplatin pretreatment. Mol Cancer Ther 2007; 6:762-72.

[31] Workman P, Twentyman P, Balkwill F, Chaplin D, Double J, Newell D, et al. United Kingdom Co-ordinating committee on Cancer Research (UKCCCR) guidelines for the welfare of animals in experimental neoplasia (second edition). Br J Cancer 1998; 77:1-10.

[32] Mollinedo F, Gajate C. Fas/CD95 death receptor and lipid rafts: new targets for apoptosis-directed cancer therapy. Drug Res Updates 2006; 9:51-73.

[33] Schutze S, Tchikov V, Schneider-Brachert W. Regulation of TNFR1 and CD95 signalling by receptor compartmentalization. Nature Rev 2008; 9:655-62.

[34] Eramo A, Sargiacomo M, Ricci-Vitiani L, Todaro M, Stassi G, Messina CG, et al. CD95 death-inducing signaling complex formation and internalization occur in lipid rafts of type I and type II cells. Eur J Immunol 2004; 34:1930-40.

[35] Mahalingam D, Szegezdi E, Keane M, de Jong S, Samali A. TRAIL receptor signalling and modulation: are we on the right TRAIL? Cancer Treat. Rev. 2009; 35:280-8.

[36] Ivanov VN, Ronai Z, Hei TK. Opposite roles of FAP-1 and dynamin in the regulation of Fas (CD95) translocation to the cell surface and susceptibility to Fas ligand-mediated apoptosis. J Biol Chem 2006; 281:1840-52.

[37] Lam ET, Ringel MD, Kloos RT, Piror TW, Knopp MV, Liang J, et al. Phase II clinical trial of sorafenib in metastatic medullary thyroid cancer. J Clin Oncol 2010; 28:2323-30.

[38] Plaza-Menacho I, Mologni L, Sala E, Gambacorti-Passerini C, Magee AI, Links TP, et al. Sorafenib functions to potently suppress RET tyrosine kinase activity by direct enzymatic inhibition and promoting RET lysosomal degradation independent of proteasomal targeting. $\mathrm{J}$ 
Biol Chemistry 2007; 282:29230-40.

[39] Cursi S, Rufini A, Stagni V, Condò I, Matafora V, Bachi A, et al. Src kinase phosphorylates Caspase-8 on Tyr380: a novel mechanism of apoptosis suppression. EMBO J 2006; 25:1895-905.

[40] Fulda S. Caspase-8 in cancer biology and therapy. Cancer Lett 2009; 28:128-33.

[41] Schenone S, Brullo C, Musumeci F, Botta M. Novel dual Src/Abl inhibitors for hematologic and solid malignancies. Expert Opin Ivestig Drugs 2010; 19:931-45.

[42] Abaan OD, Toretsky JA. PTPL1: a large phosphatase with a split personality. Cancer Met Rev 2008; 27:205-14.

[43] Fanning AS, Anderson JM. Protein-protein interactions: PDZ domain networks. Curr Biol 1996; 11:1385-8.

[44] Ostman A, Hellberg C, Bohmer FD. Protein-tyrosine phosphatases and cancer. Nature Rev 2006; 6:307-20.

[45] Schickel R, Park SM, Murmann AE, Peter ME. mir-200c regulates induction of apoptosis through CD95 by targeting FAP-1. Mol Cell 2010; 38:908-15.

[46] Myc A, Arscott PL, Bretz JD, Thomson NW, Baker JR. Characterization of FAP-1 expression and function in thyroid follicular cells. Endocrinology 1999; 140:5431-4.

[47] Kurokawa M, Kornbluth S. Caspases and kinases in a death grip. Cell 2009; 138:83854.

[48] Porter AG, Dhakshinamoorthy S. Apoptosis initiated by dependence receptors: a new paradigm for cell death? BioEssays 2004; 26:656-64.

[49] Irie S, Hachiya T, Rabizadeh S, Maruyama W, Mukai J, Li Y, et al. Functional interaction of Fas-associated phosphatase-1 (FAP-1) with p $75^{\mathrm{NTR}}$ and their effect on NF- $\mathrm{KB}$ activation. FEBS Lett 1999; 460:191-8.

[50] Bredesen DE, Mehlen P, Rabizadeh S. Apoptosis and dependence receptors: a molecular basis for cellular addiction. Physiol Rev 2004; 84:411-30.

[51] Stupack DG, Puente XS, Boutsaboualoy S, Storgard CM, Cheresh DA. Apoptosis of adherent cells by recruitment of caspase-8 to unligated integrins. J Cell Biol 2001; 155:45970.

[52] Mitsiades CS, Poulaki V, Fanourakis G, Sozopoulos E, McMillin D, Wen Z, et al. Fas signaling in thyroid carcinomas is diverted from apoptosis to proliferation. Clin Cancer Res 2006; 12:3705-12.

[53] Chaigne-Delalande B, Moreau J-F, Legembre P. Rewinding the DISC. Arch Immunol Ther Exp 2008; 56:9-14. 
[54] Wilson NS, Dixit V, Ashkenazi A. Death receptor signal transducers: nodes of coordination in immune signalling networks. Nature Immunol 2009; 10:348-55.

[55] Igney FH, Krammer PH. Death and anti-death: tumor resistance to apoptosis. Nat Rev Cancer 2002; 2:277-88.

[56] Lemmon MA, Schlessinger JS. Cell signaling by receptor tyrosine kinases. Cell 2010; 141:1117-34. 


\section{FIGURE LEGENDS}

Fig. 1. Effects of RPI-1 on Ret-MEN2B signaling and growth of MZ-CRC-1 MTC cells in vitro and in vivo. (A) Cells were treated with solvent (-) or drug $(6,20,60 \mu \mathrm{M})$ for $24 \mathrm{~h}$. Ret or phospho-tyrosine (pY) immunoprecipitates (IP) and whole cell lysates (WCL) were analyzed by Western blotting with the indicated antibodies. Tubulin is shown as a control for protein loading. (B) Growth curves of cells exposed to solvent or increasing concentrations of RPI-1, evaluated by SRB assay. Bars represent the mean of two separate experiments \pm SD, each performed in eight replicates. ${ }^{\#} \mathrm{P}<0.001,{ }^{\#} \mathrm{P}<0.0001$. (C) SCID mice inoculated s.c. with MZ-CRC-1 cells were treated orally BID with vehicle or RPI-1 for 45 days. Connected arrows indicate the beginning and the end of the treatment period. $* \mathrm{P}<0.01, * * \mathrm{P}<0.005$.

Fig. 2. Apoptosis induction in MZ-CRC-1 cells by RPI-1. (A) TUNEL staining analyzed by FACS after 7 days of drug treatment. A representative dose-response experiment is shown together with quantitative data obtained in three independent experiments. Mean percentages \pm SD. (B) Caspase activity assessed by fluorimetric assay. Lysates from cells treated with solvent (-) or RPI-1 were incubated with labeled peptide substrates specific for caspase-8, -9, or -3. Enzyme activity was detected using a fluorescence microplate reader and expressed relative to control cells. One experiment representative of two is shown. $* \mathrm{P}<0.05, * * \mathrm{P}<$ 0.0005 .

Fig. 3. Activation and potentiation of CD95-mediated apoptotic signaling by RPI-1. (A) MZCRC-1 cells were treated with solvent (-) or $60 \mu \mathrm{M}$ RPI-1 for $96 \mathrm{~h}$. The distribution of DISC components in Triton-X-100-soluble (S) and -insoluble (I) cell fractions was analyzed by Western blotting. (B) Cells were treated with solvent (-) or $30 \mu \mathrm{M}$ RPI-1 for $96 \mathrm{~h}$ and/or with $300 \mathrm{ng} / \mathrm{ml}$ of anti-CD95 mAb CH11 in the last $48 \mathrm{~h}$. Cell fractions were analyzed as in (A) 
with the indicated antibodies. In (A) and (B), actin is shown as an example of protein whose distribution is not affected by treatments. (C) and (D), cells were treated with solvent (-) or the indicated concentrations of RPI-1 for $96 \mathrm{~h}$ and/or CH11 in the last $48 \mathrm{~h}$. Cell growth (C) was evaluated by SRB assay and apoptosis (D) by cytoplasmic histone-associated DNA fragmentation assay. Bars represent mean values referred to control cells \pm SD obtained in three separate experiments. ${ }^{\#} \mathrm{SR}=1.2,{ }^{\#} \mathrm{SR}=2.1$. (E) Cells were exposed to solvent (-) or 30 $\mu \mathrm{M}$ RPI-1 and/or $300 \mathrm{ng} / \mathrm{ml} \mathrm{CH11.} \mathrm{Whole} \mathrm{cell} \mathrm{lysates} \mathrm{(WCL)} \mathrm{were} \mathrm{analyzed} \mathrm{by} \mathrm{Western}$ blotting to assess caspase and PARP cleavage. Quantitative data on these blots are provided in Supplementary data, Fig. S2. Anti-tubulin blot shows protein loading.

Fig. 4. Fap-1 levels and CD95 surface levels are inversely regulated by RPI-1 in MZ-CRC-1 cells. (A) Kinetics of RPI-1 effects on Fap-1 protein levels, caspase activation and AKT/ERK signaling. Lysates from cells treated with solvent (-) or $60 \mu \mathrm{M}$ RPI-1 for the indicated times were subjected to Western blot analysis with the indicated antibodies. For the detection of activating phosphorylations of AKT (pAKT) and ERK (pERK), filters were probed with phospho-specific antibodies and then blots were stripped and reprobed with antibodies directed against the respective proteins. (B) CD95 cell surface expression in cells treated with solvent (control) or RPI-1 at $30 \mu \mathrm{M}$ and $60 \mu \mathrm{M}$ for $96 \mathrm{~h}$ (upper panel) or RPI-1 at $60 \mu \mathrm{M}$ for $48 \mathrm{~h}, 72 \mathrm{~h}$, and $96 \mathrm{~h}$ (lower panels). Cells were incubated with rabbit anti-CD95 antibody and then stained with Alexa Fluor 488 dye-conjugated anti-rabbit antibody followed by flow cytometry analysis. Shadowed histograms represent no primary antibody controls. Data are representative of three independent experiments.

Fig. 5. Ret-MEN2B interacts with Fap-1 and regulates its levels in MZ-CRC-1 cells. (A) Cells were transfected with control or RET siRNA, or treated with the transfection reagent 
(Lipo2000) alone. After $48 \mathrm{~h}$, cells were subjected to an additional round of transfection and incubated with RPI-1 $(60 \mu \mathrm{M})$ as indicated. Cell lysates were prepared $48 \mathrm{~h}$ later and analyzed for Ret and Fap-1 expression by Western blot. Values obtained by densitometric analysis of bands, normalized vs tubulin, are reported. (B) HEK293 cells were transiently transfected with increasing amounts $(4$ and $8 \mu \mathrm{g})$ of RETM918T expression vector $\left(\mathrm{RET}^{\mathrm{MEN} 2 \mathrm{~B}}\right)$. Cell lysates prepared after $48 \mathrm{~h}$ were probed with the indicated antibodies by Western blotting to detect Ret expression and activation, as well as Fap-1 expression. Protein loading was controlled by tubulin (A) or Hsp90 (B). (C) Cells were treated with solvent (-) or $60 \mu \mathrm{M}$ RPI$1(+)$ for $24 \mathrm{~h}$ and then subjected to immunoprecipitation (IP) with anti-Ret or anti-Fap-1 antibody. Immunoprecipitates were probed by Western blotting with the same antibodies or anti-phosphotyrosine (pY) antibody. As a control, Ret and Fap-1 protein levels were detected in whole cell lysates (WCL). Tubulin shows protein loading. (D) Confocal fluorescence microscopy showing Ret (red) and Fap-1 (green) immunodetection. Yellow staining indicates co-localization of the two proteins. Images show one single frame out of 26 . Scale bar $=10$ $\mu \mathrm{m}$. Representative data from two to three independent experiments are shown.

Fig. 6. Role of caspases in Ret and Fap-1 downregulation induced by RPI-1 in MZ-CRC-1 cells. (A) The CD95 agonist antibody CH11 alone does not modulate Fap-1 protein levels but enhances RPI-1-induced Fap-1 downregulation. Cells were incubated with solvent (-) or 30 $\mu \mathrm{M}$ RPI-1 for $96 \mathrm{~h}$ in the presence or absence of $300 \mathrm{ng} / \mathrm{ml} \mathrm{CH11} \mathrm{in} \mathrm{the} \mathrm{last} 48 \mathrm{~h}$. (B) Effect of caspase peptide inhibitors on RPI-1-induced downregulation of Ret and Fap-1 cellular levels. Cells were pre-incubated with $50 \mu \mathrm{M}$ z-VAD (broad-spectrum caspase inhibitor), zLEHD (caspase-9 inhibitor) or Z-IETD (caspase-8 inhibitor) for $1 \mathrm{~h}$ and then exposed to solvent or $60 \mu \mathrm{M}$ RPI-1 for 48 h. (C) Procaspase- 8 co-immunoprecipitation with Ret. Cells treated with solvent (-) or $60 \mu \mathrm{M}$ RPI-1 for $6 \mathrm{~h}$ were processed for immunoprecipitation (IP) 
with anti-Ret antibody or whole cell lysate (WCL) preparation. (D) Inhibition of procaspase-8 tyrosine phosphorylation in cells treated with RPI-1. Cells exposed to increasing drug concentrations $(6,20,60 \mu \mathrm{M})$ for $24 \mathrm{~h}$ were subjected to IP with anti-phosphotyrosine antibody (pY) or WCL preparation. In each panel, samples were probed with specific antibodies by Western blotting. Tubulin blots represent protein loading controls. 
A
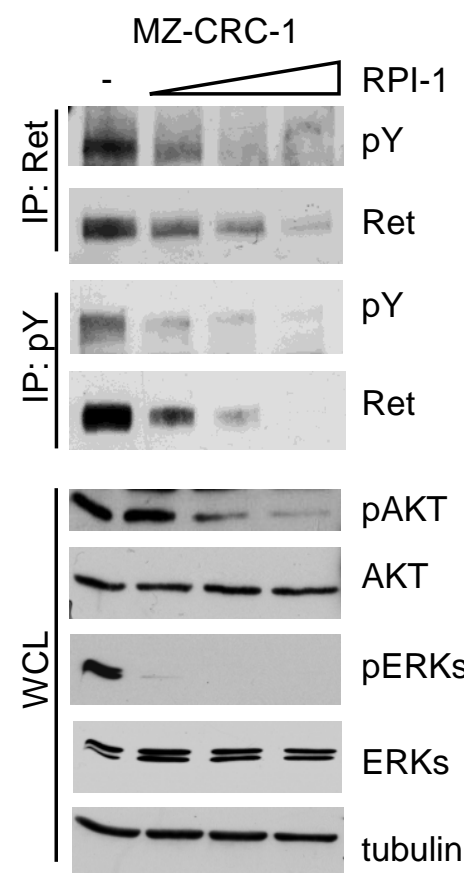

B

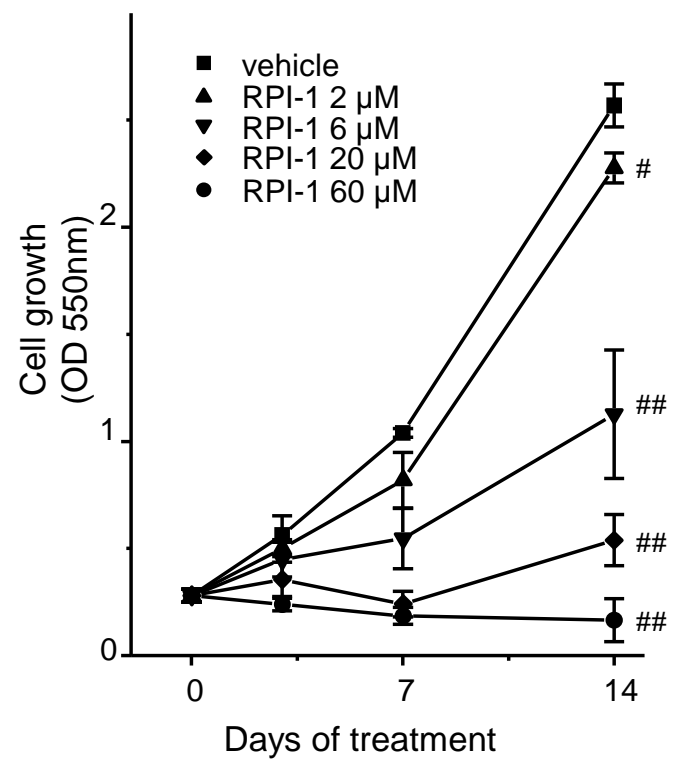

C

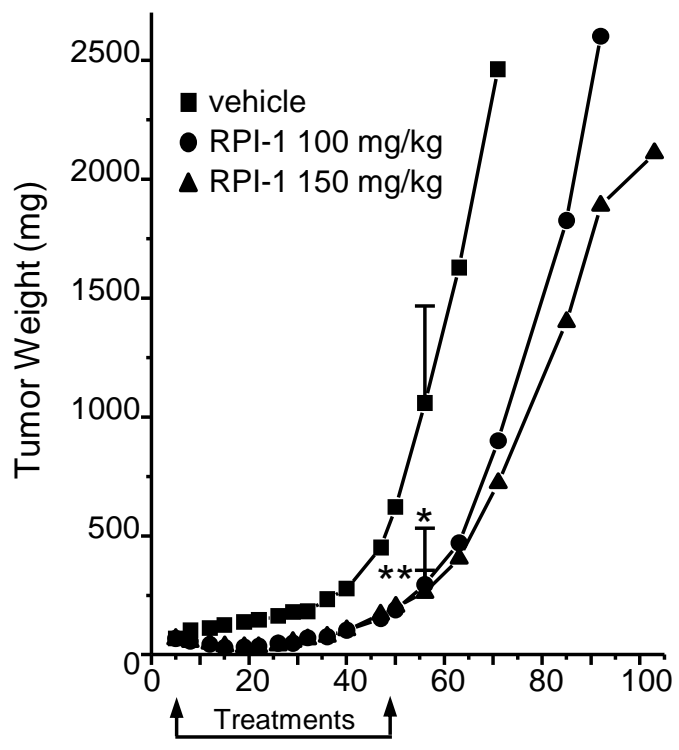

Days after tumor inoculum
Nicolini Fig. 1 
A
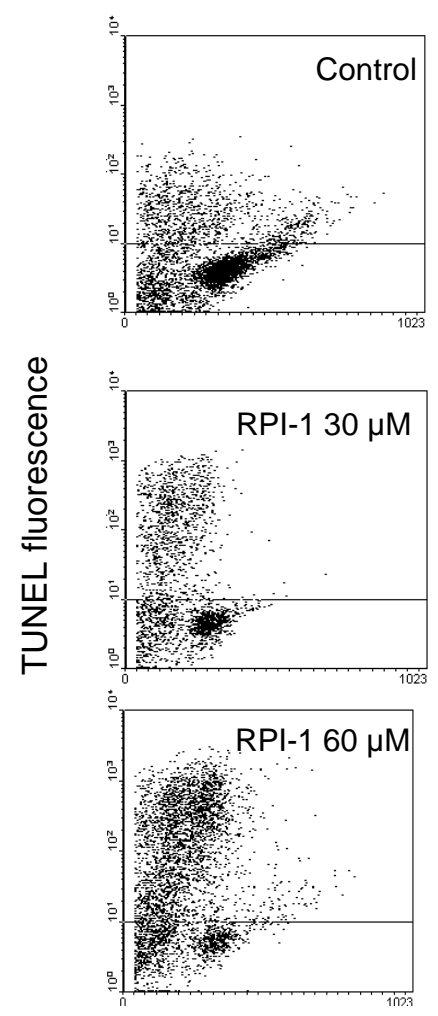

Forward Scatter

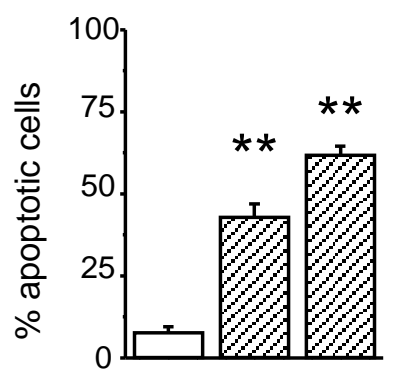

RPI-1 $(\mu \mathrm{M})$

\section{B}
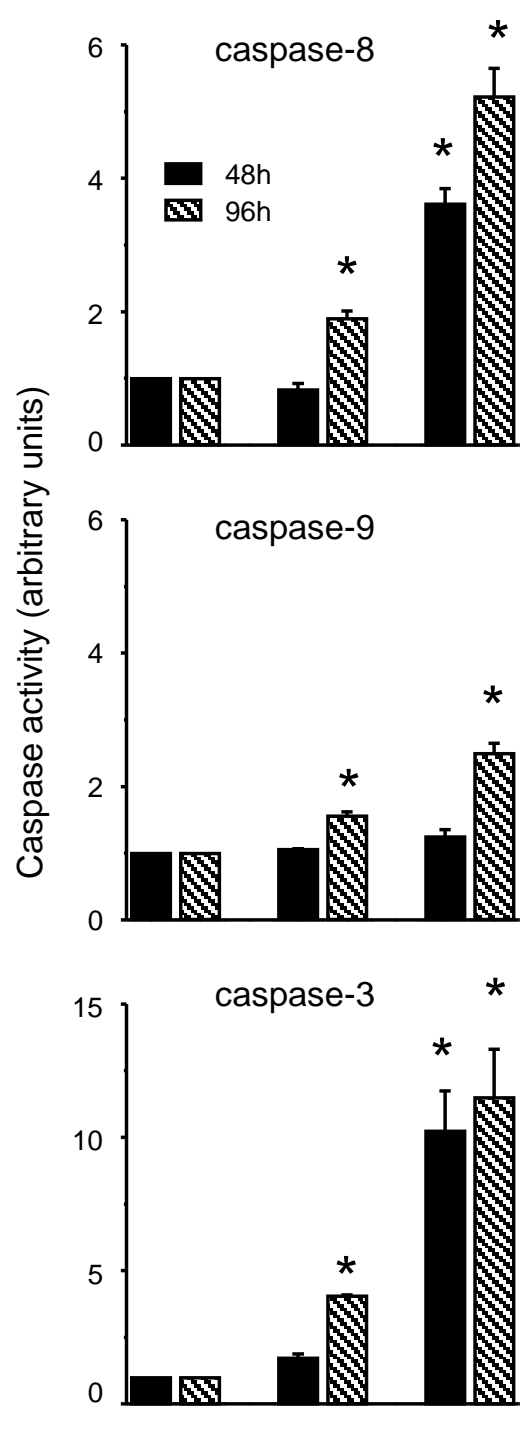

RPI-1 $(\mu \mathrm{M}) \quad-\quad 30 \quad 60$ 
Figure 3

A

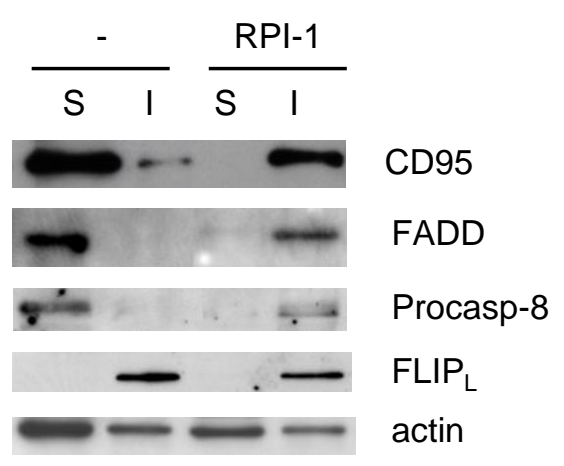

B

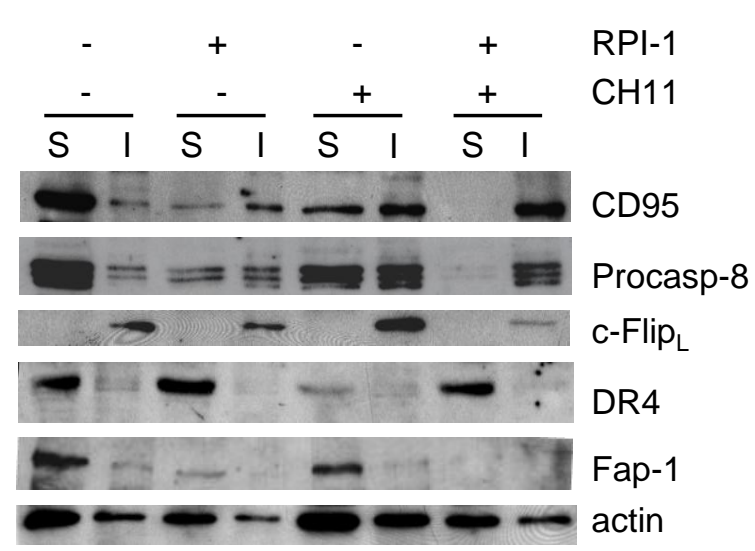

C

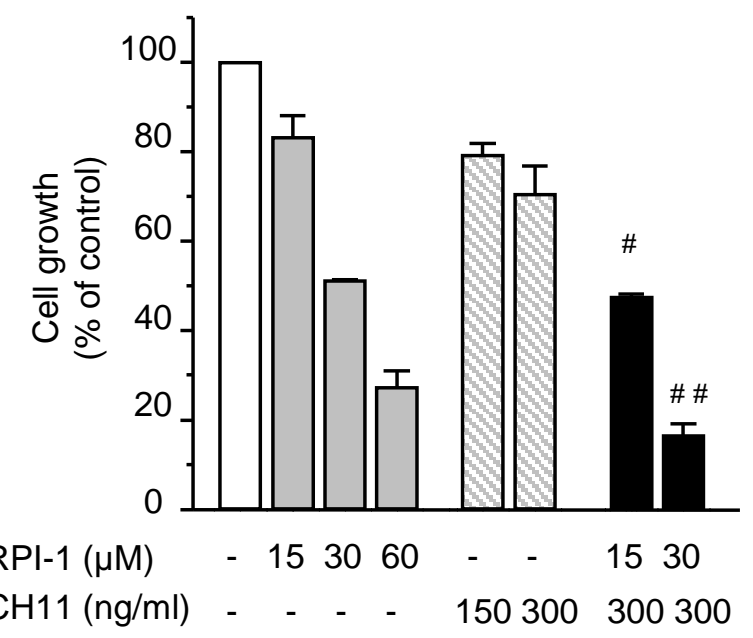

E

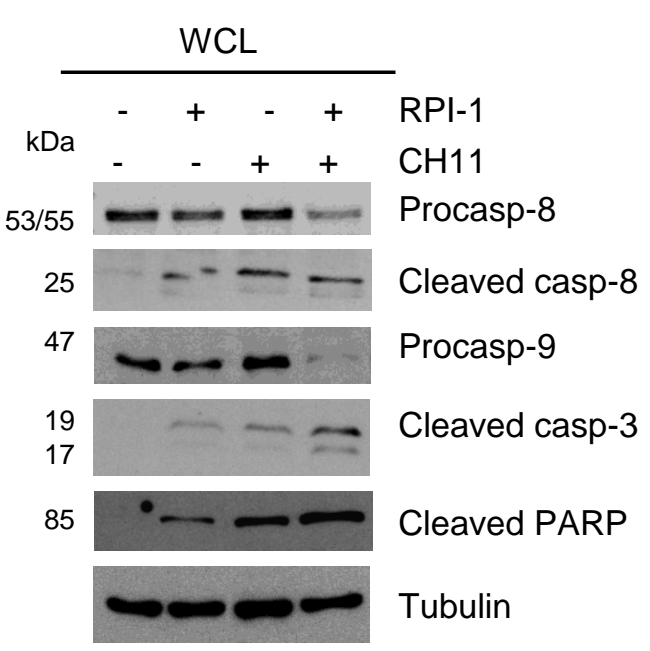

D

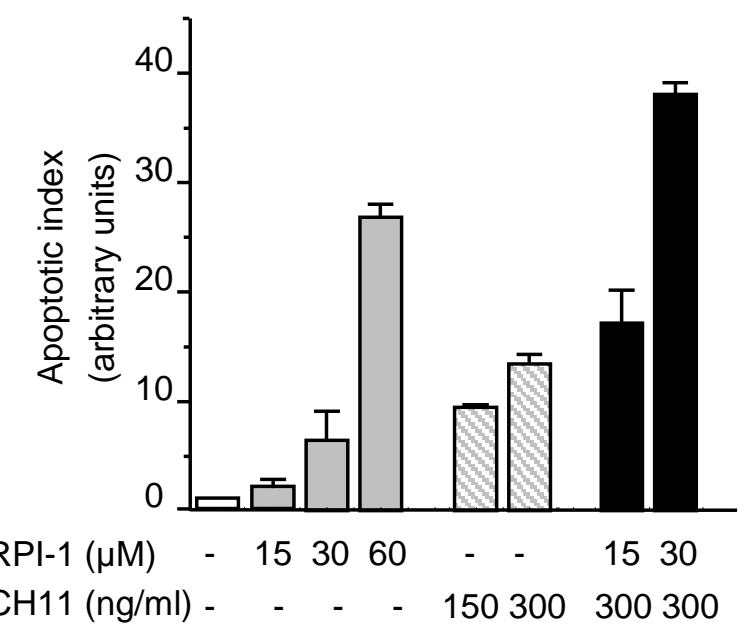


Figure 4

A

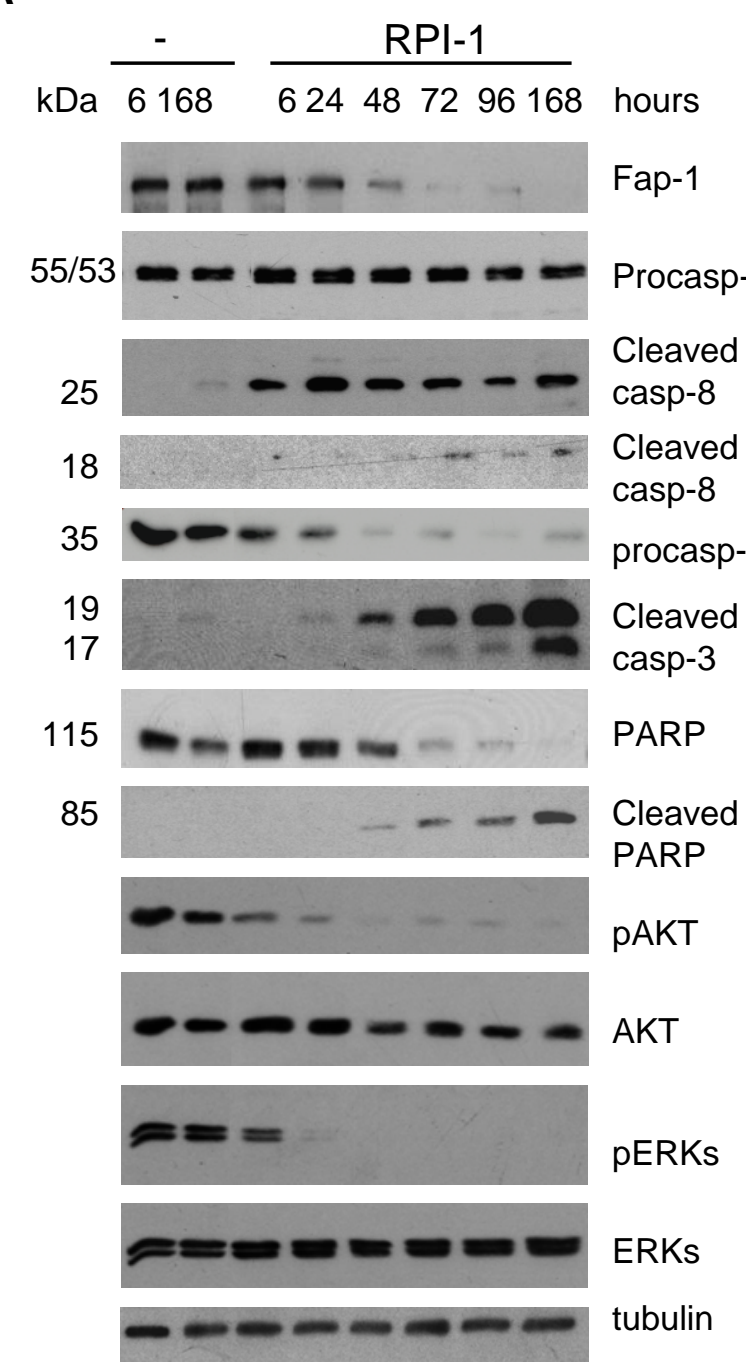

B

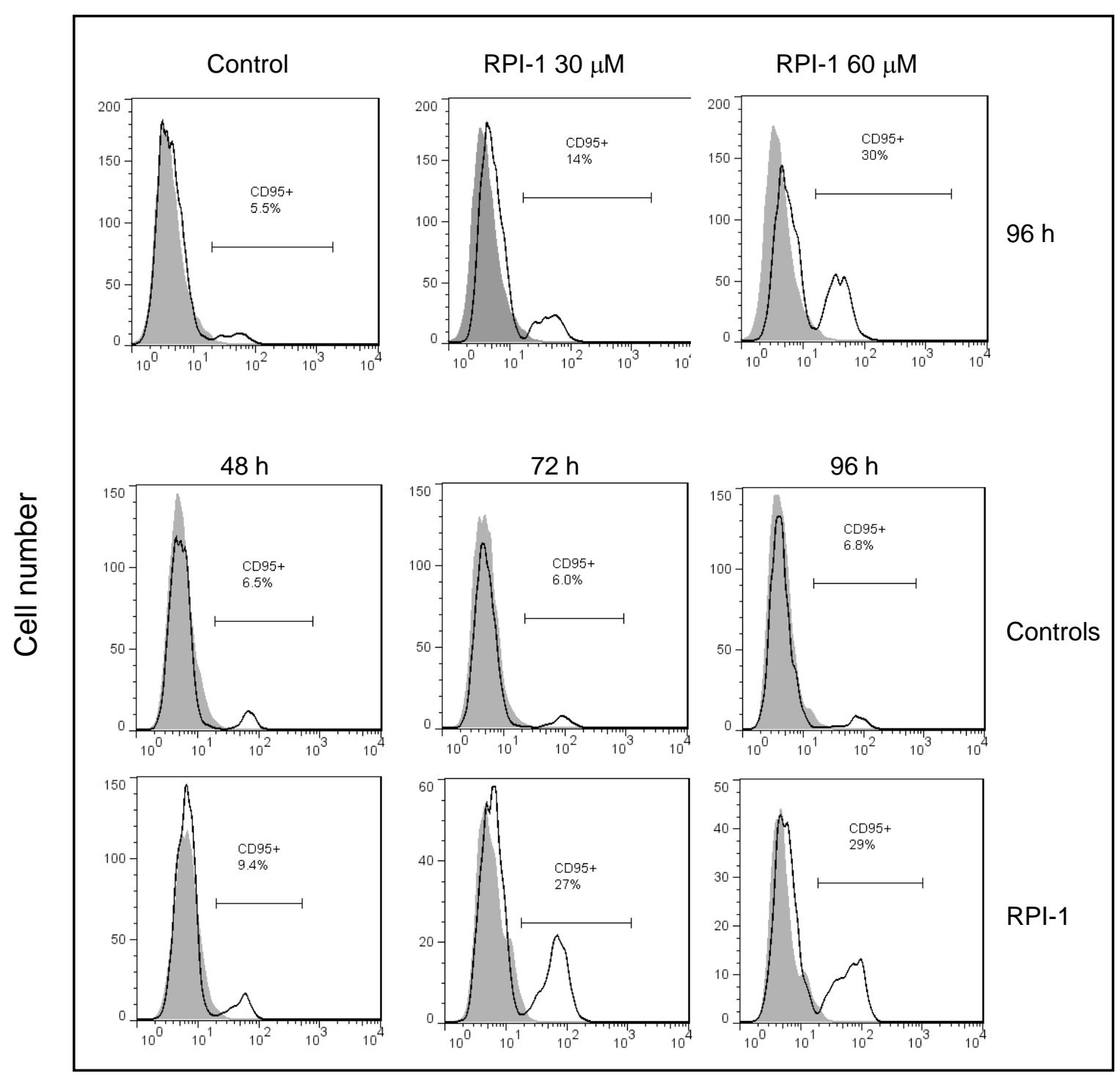

Surface CD95 levels

Nicolini Fig. 4 
A

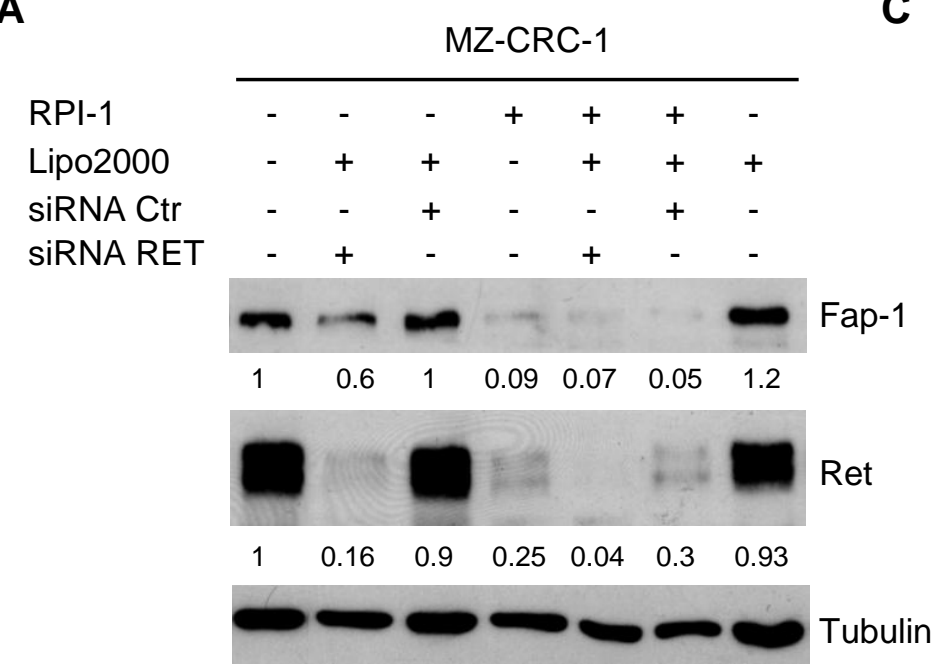

B

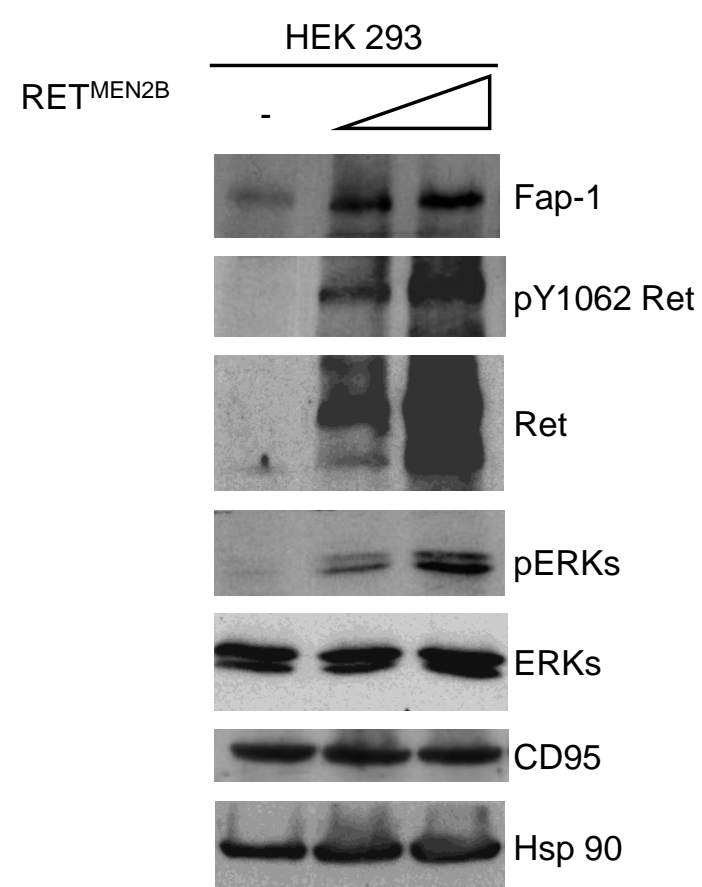

RPI-1
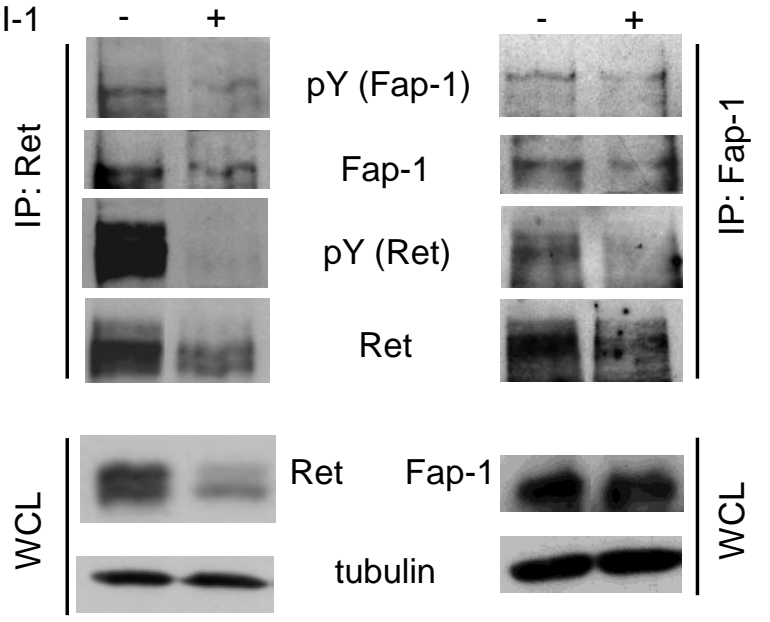

D

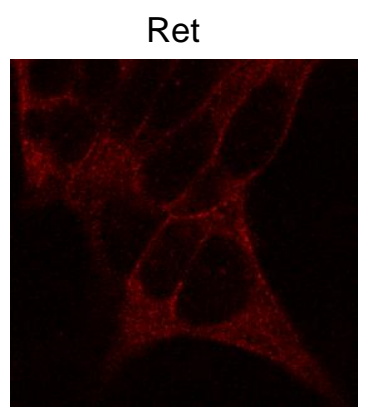

Fap-1

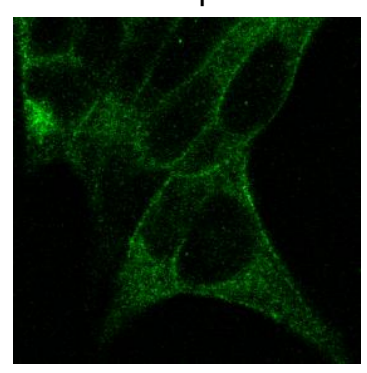

Merge

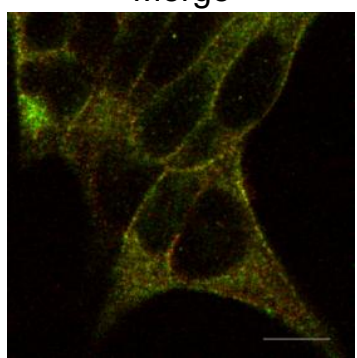


A

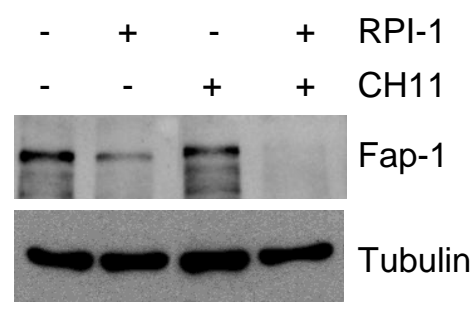

C

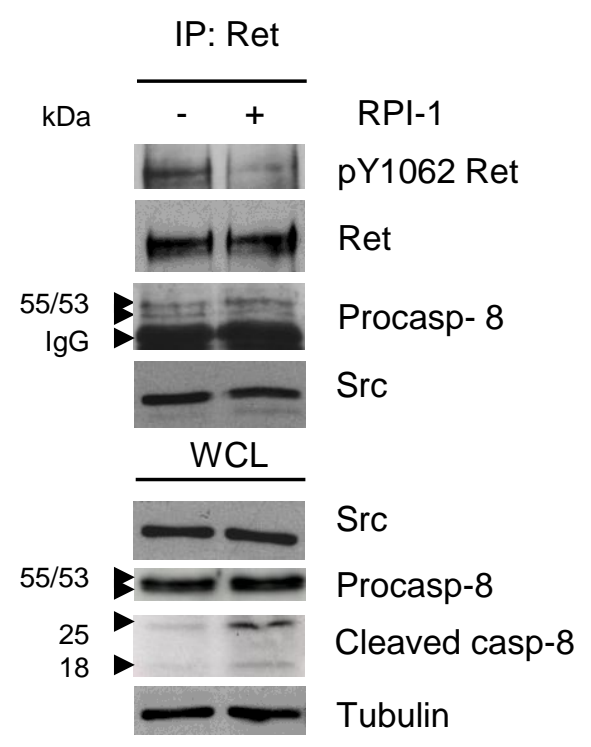

B

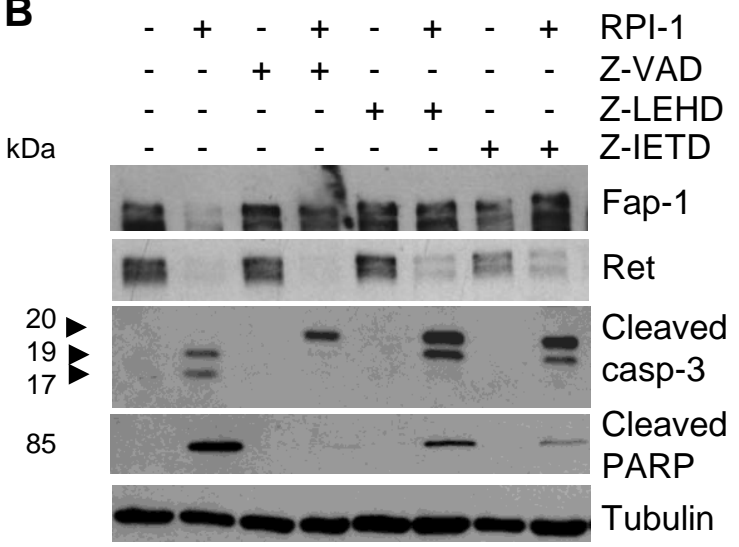

D

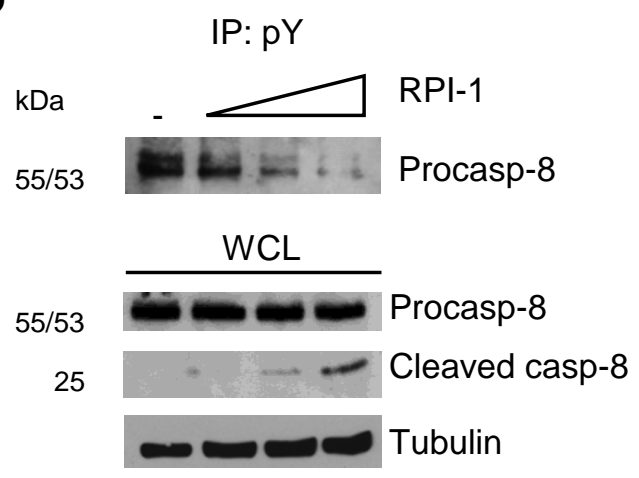

Nicolini Fig. 6 


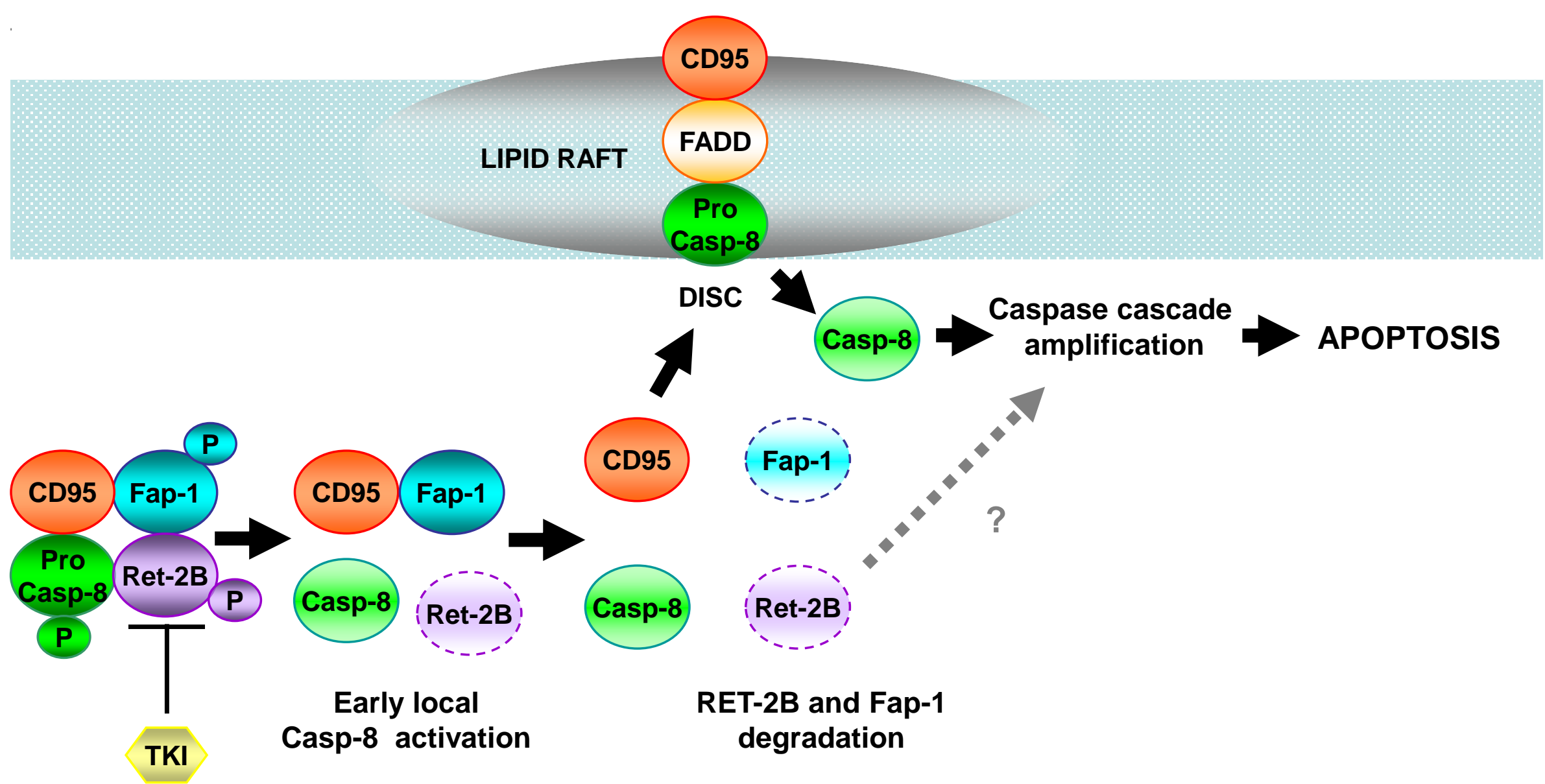

